\title{
HIV status alters disease severity and immune cell responses in $\beta$ variant SARS-CoV-2 infection wave
}

Farina Karim ${ }^{1,2 \dagger}$, Inbal Gazy ${ }^{2,3} \dagger$, Sandile Cele ${ }^{1,2} \dagger$, Yenzekile Zungu ${ }^{1 \dagger}$, Robert Krause ${ }^{1,2} \dagger$, Mallory Bernstein $^{1}$, Yashica Ganga ${ }^{1}$, Hylton Rodel ${ }^{1,4}$, Ntombifuthi Mthabela ${ }^{1}$, Matilda Mazibuko ${ }^{1}$, Khadija $\mathrm{Khan}^{1}$, Daniel Muema ${ }^{1,2}$, Dirhona Ramjit ${ }^{1}$, Thumbi Ndung' ${ }^{1}{ }^{1,4,6,7}$, Willem Hanekom ${ }^{1,4}$, Bernadett I. Gosnell $^{9}$, COMMIT-KZN Team ${ }^{\S}$, Richard Lessells ${ }^{3}$, Emily Wong ${ }^{1,8}$, Tulio de Oliveira ${ }^{3}$, Mahomed-Yunus S. Moosa ${ }^{9}$, Gila Lustig ${ }^{5}$, Alasdair Leslie ${ }^{1,4^{*}}$, Henrik Kløverpris ${ }^{1,4,10^{*}}$, Alex Sigal ${ }^{1,2,7^{*}}$

${ }^{1}$ Africa Health Research Institute, Durban 4001, South Africa. ${ }^{2}$ School of Laboratory Medicine and Medical Sciences, University of KwaZulu-Natal, Durban 4001, South Africa. ${ }^{3}$ KwaZulu-Natal Research Innovation and Sequencing Platform, Durban 4001, South Africa. ${ }^{4}$ Division of Infection and Immunity, University College London, London WC1E 6BT, UK. ${ }^{5}$ Centre for the AIDS Programme of Research in South Africa, Durban 4001, South Africa. ${ }^{6}$ HIV Pathogenesis Programme, The Doris Duke Medical Research Institute, University of KwaZulu-Natal, Durban 4001, South Africa. ${ }^{7}$ Max Planck Institute for Infection Biology, Berlin 10117, Germany. ${ }^{8}$ Division of Infectious Diseases, University of Alabama at Birmingham, Birmingham, AL 35294, USA. ${ }^{9}$ Department of Infectious Diseases, Nelson R. Mandela School of Clinical Medicine, University of KwaZulu-Natal, Durban 4001, South Africa. ${ }^{10}$ Department of Immunology and Microbiology, University of Copenhagen, Copenhagen 2200N, Denmark.

$\dagger$ Equal contribution

$\S$ The names/affiliations of COMMIT-KZN Team members not listed separately appear at end of paper

* Corresponding author. Email: al.leslie@ahri.org, henrik.kloverpris@ahri.org, alex.sigal@ahri.org 


\section{Abstract}

2 There are conflicting reports on the effects of HIV on COVID-19. Here we analyzed disease severity and immune cell changes during and after SARS-CoV-2 infection in 236 participants from South Africa, of which $39 \%$ were people living with HIV (PLWH), during the first and second ( $\beta$ dominated) infection waves. The second wave had more PLWH requiring supplemental oxygen relative to HIV negative participants. Higher disease severity was associated with low CD4 T cell counts and higher neutrophil to lymphocyte ratios (NLR). Yet, CD4 counts recovered and NLR stabilized after SARS-CoV-2 clearance in wave 2 infected PLWH, arguing for an interaction between SARS-CoV-2 and HIV infection leading to low CD4 and high NLR. The first infection wave, where severity in HIV negative and PLWH was similar, still showed some HIV modulation of SARS-CoV-2 immune responses. Therefore, HIV infection can synergize with the SARS-CoV-2 variant to change COVID-19 outcomes.

\section{Introduction}

HIV is a prevalent infection in KwaZulu-Natal, South Africa [1] which also has a high SARS-CoV-2 attack rate [2,3]. HIV depletes CD4 T helper cells [4] which are a critical part of the adaptive immune response and are also the main target of HIV infection. CD4 T cell death occurs after infection with HIV [5], or in bystander or incompletely infected cells due to activation of cellular defense programs [6, 7], and is halted and, to some extent, reversed by antiretroviral therapy (ART), even sub-optimal therapy [8].

The loss of CD4 T cells leads to dysregulation of many aspects of the immune response, including germinal center formation and antibody affinity maturation, which requires help from the highly HIV susceptible CD4 T follicular helper cells [9-11]. In association with this, HIV also causes B cell dysregulation and dysfunction [12]. Moreover, T cell trafficking, activation, and exhaustion profiles of both CD4 and CD8 subsets are also modulated by HIV infection [13-15].

Both antibody and $\mathrm{T}$ cell responses are critical for effective control and clearance of SARS-CoV-2. More severe COVID-19 disease correlates with lymphopenia and low T cell concentrations [16-18], whilst mild disease correlates with a robust $\mathrm{T}$ cell response to SARS-CoV-2 [17, 19-24]. Neutralizing antibodies and associated expansion of antibody secreting B cells (ASC) are elicited in most SARS-CoV-2 infected individuals [25-27], and neutralizing antibody titers strongly correlate with vaccine efficacy [28, 29], indicating their key role in the response to SARS-CoV-2 infection. In contrast, high neutrophil numbers are associated with more severe disease and an elevated neutrophil to lymphocyte ratio (NLR) is often considered a risk factor for a more severe COVID-19 outcome [30-32].

Results from epidemiological studies of the interaction between HIV and SARS-CoV-2 from other locations are mixed. Several large studies observed that disease severity and/or mortality risk is increased with HIV infection [33-38] while others found no statistically significant differences in clinical presentation, adverse outcomes, or mortality [39-49]. Worse outcomes for PLWH tended to be in patients with low CD4 [37, 44, 50] and low absolute CD4 count was a risk factor for more severe disease [33].

HIV is known to interfere with protective vaccination against multiple pathogens [51-54], typically as a consequence of sub-optimal antibody responses. In line with this, results from a South-African phase IIb trial of the Novavax NVX-CoV2373 vaccine, which uses a stabilised prefusion spike protein, showed $60 \%$ efficacy in HIV-uninfected individuals. However, overall efficacy dropped to $49 \%$ upon inclusion of PLWH [55], although it is important to note that the numbers of PLWH in the study were very small. Nonetheless, there were more breakthrough cases in PLWH in the vaccine arm than the placebo arm.

An important consideration in infections in South Africa is the infecting variant, which in the second infection wave peaking January 2021 was predominantly the B.1.351 variant of concern (VOC) now designated as the $\beta$ variant. In the current third infection wave it is predominantly the B.1.617.2 $\delta$ variant. We and others have shown that the $\beta$ variant has evolved the ability to escape neutralization by antibody responses elicited by earlier strains of SARS-CoV-2 or by vaccines based on those strains [56-59]. Loss of vaccine efficacy of the AstraZeneca ChAdOx vaccine in South Africa was associated 
Table 1: Participant characteristics by HIV status

\begin{tabular}{|c|c|c|c|c|c|}
\hline & $\begin{array}{c}\text { All } \\
(n=236)\end{array}$ & $\begin{array}{c}\text { HIV- } \\
(n=143,60.6 \%)\end{array}$ & $\begin{array}{c}\text { HIV+ } \\
(n=93,39.4 \%)\end{array}$ & $\begin{array}{l}\text { Odds Ratio } \\
(95 \% \mathrm{Cl})\end{array}$ & p-value ${ }^{\#}$ \\
\hline \multicolumn{6}{|l|}{ Demographics } \\
\hline Age years, median (IQR) & $\begin{array}{c}45 \\
(35-57)\end{array}$ & $\begin{array}{c}49 \\
(35-62)\end{array}$ & $\begin{array}{c}41 \\
(35-50)\end{array}$ & & $0.003^{*}$ \\
\hline Male sex, n (\%) & $82(34.7)$ & 48 (33.6) & $34(36.6)$ & $\begin{array}{c}1.1 \\
(0.7-2.0)\end{array}$ & 0.68 \\
\hline Current smoker, n (\%) & $13(5.51)$ & $4(2.8)$ & $9(9.7)$ & $\begin{array}{c}3.7 \\
(1.2->10)\end{array}$ & 0.038 \\
\hline \multicolumn{6}{|l|}{ Comorbidity, n (\%) } \\
\hline Hypertension $\$$, n=235 & $57(24.15)$ & $42(29.4)$ & $15(16.1)$ & $\begin{array}{c}0.5 \\
(0.2-0.9)\end{array}$ & 0.023 \\
\hline Diabetes & $42(17.8)$ & $32(22.4)$ & $10(10.8)$ & $\begin{array}{c}0.4 \\
(0.2-0.9)\end{array}$ & 0.024 \\
\hline Obesity $^{\$}, \mathrm{n}=221$ & $91(42.3)$ & $64(47.1)$ & $27(29.0)$ & $\begin{array}{c}0.6 \\
(0.3-1.0)\end{array}$ & 0.086 \\
\hline Active TB & $10(4.2)$ & $1(0.7)$ & $9(9.7)$ & $>10$ & 0.001 \\
\hline History TB & $32(13.6)$ & $3(2.1)$ & $29(31.2)$ & $>10$ & $<0.0001$ \\
\hline \multicolumn{6}{|l|}{ HIV associated parameters } \\
\hline HIV viremic, $n$ (\% of all HIV) & - & - & $28(30.1)$ & - & - \\
\hline Years ART, median (IQR) & - & - & $\begin{array}{c}9.4 \\
(3.9-13.2)\end{array}$ & - & - \\
\hline $\begin{array}{c}\mathrm{CD} 4 \text { cells } / \mu \mathrm{L}, \\
\text { median (IQR) } \mathrm{n}=221\end{array}$ & $\begin{array}{c}633 \\
(326-974)\end{array}$ & $\begin{array}{c}886.5 \\
(534-1148)\end{array}$ & $\begin{array}{c}464 \\
(200-702)\end{array}$ & - & $<0.0001^{*}$ \\
\hline $\begin{array}{c}\mathrm{CD} 4 / \mathrm{CD} 8, \\
\text { median (IQR) } \mathrm{n}=221\end{array}$ & $\begin{array}{c}1.2 \\
(0.8-1.7)\end{array}$ & $\begin{array}{c}1.6 \\
(1.2-2.1)\end{array}$ & $\begin{array}{c}0.8 \\
(0.4-1.1)\end{array}$ & - & $<0.0001^{*}$ \\
\hline \multicolumn{6}{|l|}{ Disease severity, $n(\%)$} \\
\hline Asymptomatic & $33(14.0)$ & $25(17.5)$ & $8(8.6)$ & $\begin{array}{c}0.4 \\
(0.2-1.0)\end{array}$ & 0.058 \\
\hline $\begin{array}{l}\text { Ambulatory with } \\
\text { symptoms }\end{array}$ & $128(54.2)$ & $80(55.9)$ & $48(51.6)$ & $\begin{array}{c}0.8 \\
(0.5-1.4)\end{array}$ & 0.59 \\
\hline Supplemental oxygen & $62(26.3)$ & $30(21.0)$ & $32(34.4)$ & $\begin{array}{c}2.0 \\
(1.1-3.5)\end{array}$ & 0.024 \\
\hline Death & $13(5.5)$ & $8(5.6)$ & $5(5.4)$ & $\begin{array}{c}1.0 \\
(0.3-2.9)\end{array}$ & $>0.99$ \\
\hline \multicolumn{6}{|l|}{ COVID-19 treatment, n (\%) } \\
\hline Corticosteroids & $74(31.2)$ & $47(32.9)$ & $27(29.0)$ & $\begin{array}{c}0.8 \\
(0.5-1.5)\end{array}$ & 0.57 \\
\hline Anticoagulants & $53(22.5)$ & $35(24.5)$ & 18 (19.4) & $\begin{array}{c}0.7 \\
(0.4-1.4)\end{array}$ & 0.43 \\
\hline \multicolumn{6}{|l|}{ Symptom, n (\%) } \\
\hline Sore throat & $88(37.3)$ & $55(38.5)$ & $33(35.5)$ & $\begin{array}{c}0.9 \\
(0.5-1.5)\end{array}$ & 0.68 \\
\hline Runny nose & $53(22.5)$ & $30(21.0)$ & $23(24.7)$ & $\begin{array}{c}1.2 \\
(0.7-2.3)\end{array}$ & 0.53 \\
\hline Cough & $153(64.8)$ & $91(63.6)$ & $62(66.7)$ & $\begin{array}{c}1.1 \\
(0.7-2.0)\end{array}$ & 0.68 \\
\hline History of fever $\$$ n=235 & $58(24.7)$ & $29(20.3)$ & $29(31.2)$ & $\begin{array}{c}1.8 \\
(1.0-3.3)\end{array}$ & 0.063 \\
\hline Shortness of breath & $148(62.7)$ & $87(60.8)$ & $61(65.6)$ & $\begin{array}{c}1.2 \\
(0.7-2.1)\end{array}$ & 0.49 \\
\hline
\end{tabular}

\#p-value calculated via 2-sided Fisher's Exact test, except for * which was calculated via Mann-Whitney U test. ${ }^{5}$ Not including pregnancy or unable to be measured. 
with this drop in neutralization capacity [60]. The second infection wave driven by $\beta$ infections also showed increased mortality of hospitalized cases vrelative to the first infection wave [61].

What factors contributed to the evolution of the $\beta$ variant in South Africa is yet unclear. One possibility is intra-host evolution in immunosuppressed PLWH with advanced HIV who are unable to clear SARS-CoV-2 [62]. There is also evidence that variants evolved other adaptations to the host in addition to those in the spike glycoprotein which lead to antibody escape and enhanced transmission. These include evolution of resistance to the host interferon response [63, 64], as well as enhanced cell-to-cell transmission [65]. Changes in the virus may make infection with some variants of concern (VOC) substantially different in disease course, transmission dynamics, and effect on PLWH relative to ancestral SARS-CoV-2 strains or possibly other variants.

Here we aimed to determine the effects of HIV on the immune response to SARS-CoV-2 infection in KwaZulu-Natal, South Africa. This is important because we need to better understand COVID-19 disease course and vaccine efficacy in this population, as well as the possible reasons for the emergence of the currently circulating variants which lead to immune escape from neutralizing antibodies. Our results indicate that infections in the $\beta$ variant infection wave led to more severe disease in PLWH relative to HIV negative participants. Higher severity was associated with a lower CD4 T cell count. Yet, the CD4 count recovered, indicating that these participants may not have had a low CD4 count when first exposed to SARS-CoV-2. In addition, there were changes in the response of immune cell subsets associated with SARS-CoV-2 infection in PLWH relative to HIV negative participants in the first infection wave, even in the absence of a statistically significant increase in disease severity, indicating that HIV infection may modulate the immune response to SARS-CoV-2.

\section{Results}

\section{HIV infection is associated with higher disease severity in the $\beta$ variant infection wave}

We initiated a longitudinal observational cohort study to enroll and track patients with a positive COVID-19 qPCR test presenting at three hospitals in Durban, South Africa. Patients presented due to either COVID-19 symptoms or because they were known contacts of a confirmed COVID-19 case.

A

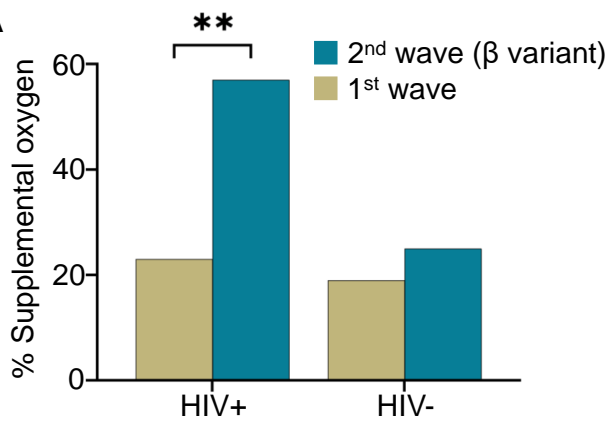

B

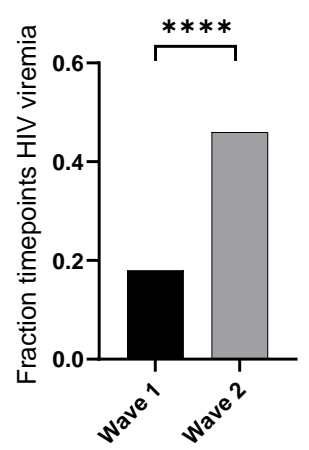

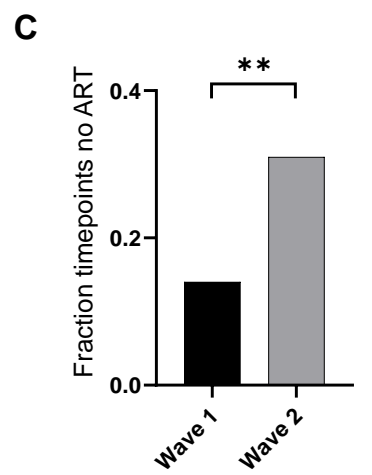

Figure 1: Differences in PLWH COVID-19 outcome and ART suppression between waves. (A) Fraction of PLWH and HIV negative participants requiring supplemental oxygen during the first and the $\beta$ VOC dominated second infection waves in South Africa. $p=0.0025$ by Fisher's Exact test. (B) Frequency of HIV viremia in wave 1 versus wave 2 . Frequency was calculated as the number of study timepoints in wave 1 or wave 2 with HIV RNA > 200 copies/ml divided by all measured timepoints for PLWH. (C) The fraction of timepoints with no detectable ART in wave 1 versus wave 2 . Fraction was calculated as the number of study timepoints in wave 1 or wave 2 where the concentration of none of the ART components was above level of quantification ivided by all measured PLWH timepoints. p-values are ${ }^{*}<0.05 ;^{* *}<0.01 ; * * *<0.001,{ }^{* * * *}<0.0001$ as determined by Fisher's Exact test. 
All participants were initially admitted to a hospital facility, then discharged after varying periods and followed up as outpatients. Enrollment was between June 2020 and May 2021. Participants were followed up weekly for the first month post-enrollment, and at 3 month intervals thereafter. At each study visit, a blood sample and a combined nasopharyngeal and oropharyngeal swab was taken. The purpose of a combined swab was to maximize the detection probability by qPCR of SARS-CoV-2 in the upper respiratory tract. Blood was used to determine HIV status, HIV viral load, and cellular parameters such as the concentration of CD4 $\mathrm{T}$ cells and the neutrophil to lymphocyte ratio. We also tested the frequencies more specific immune cell subsets by flow cytometry (only available for infection wave 1 samples).

Up to May 2021, 236 participants were enrolled in the study, for a total of 986 study visits (Supplementary File 1). All participants are assumed to be vaccinated with BCG in infancy in accordance with South African national guidelines. The majority of participants were female, possibly reflecting better linkage to care. Enrollment was a median 11 days post-symptom onset (Supplementary File 2). De-identified participant data used here are available as a Source Data 1 included in the supplementary materials.

Out of 236 study participants, 93 (39\%) were PLWH (Table 1) and $89 \%$ of study participant were of African descent. PLWH were significantly younger than HIV uninfected participants. Hypertension, diabetes and obesity, known risk factors for more severe COVID-19 disease [47, 66], were common: Hypertension and obesity were present in $24 \%$, and $42 \%$ of study participants respectively, a similar prevalence to that reported in the province of KwaZulu-Natal where this study was performed [67, 68]. Diabetes prevalence in our study was $18 \%$, compared to $13 \%$ reported for South Africa [69]. Hypertension and diabetes were significantly lower in the PLWH group (Table 1). 28 or $30 \%$ of PLWH were HIV viremic at any point in the study. For individuals on ART, median ART duration was 9 years. ART regimen was determined by liquid chromatography with tandem mass spectrometry (LC-MS-MS) and was predominately efavirenz (EFV) based, with some participants transitioning to a dolutegravir (DTG) based regimen. In addition, there was a small subset of PLWH on a ritonavir boosted lopinavir (LPV/r) as well as other ART combinations and about $12 \%$ of PLWH had no detectable ART despite a clinical record of ART, or were ART naive (Supplementary File 3). The absolute CD4 T cell count and the CD4 to CD8 T cell ratio was significantly lower in PLWH relative to HIV negative participants at enrollment. The incidence of active TB and the fraction of participants with a history of TB were much higher in the PLWH group (Table 1).

A minority of study participants (14\%) were asymptomatic and presented at the hospital because of a close contact with a confirmed COVID-19 case. To include the asymptomatic participants in our analysis, we used time from diagnostic swab as our timescale, which was tightly distributed for symptomatic participants relative to symptom onset at a median of 3 to 4 days apart (Supplementary File 2).

The majority of participants in the study $(54 \%)$ had symptoms but did not progress beyond mild disease, defined here as not requiring supplemental oxygen during the course of disease and convalescence. $26 \%$ of participants required supplemental oxygen but did not die and $6 \%$ of participants died. Our cohort design did not specifically enroll critical SARS-CoV-2 cases. The requirement for supplemental oxygen, as opposed to death, was therefore our primary measure for disease severity.

There was a significant difference in the frequency of participants requiring supplemental oxygen (without subsequent death) between HIV negative participants and PLWH (21\% versus $34 \%$ respectively, odds ratio of 2.0 with $95 \%$ confidence intervals of 1.1-3.5, Table 1 ).

To determine if the fraction of participants requiring supplemental oxygen differed between the first infection wave and the $\beta$ variant dominated second infection wave, we compared disease severity between the first infection wave (Figure 1, Supplementary File 4), and the second infection wave (Figure 1, Supplementary File 5). In the first infection wave, there was no significant difference in the fraction of participants requiring supplemental oxygen between HIV negative and PLWH participants (Supplementary File 4, $\mathrm{p}=0.5$ ). However, significantly more PLWH required supplemental oxygen in the second wave (Supplementary File 5, odds ratio of 4.0 with 95\% CI of 1.6-10.4, $\mathrm{p}=0.005$ ). Comparing within the HIV negative and PLWH groups, there was only a moderate increase in the fraction of participants requiring supplemental oxygen between SARS-CoV-2 infection wave 1 and infection wave 2 in HIV negative participants (19\% to $25 \%$ ) which was not significant (Figure 1A). In contrast, the 
Table 2: Characteristics by HIV status of participants requiring supplemental oxygen

\begin{tabular}{|c|c|c|c|c|c|}
\hline & $\begin{array}{c}\text { All } \\
(n=68)\end{array}$ & $\begin{array}{c}\text { HIV- } \\
(n=35,51.5 \%)\end{array}$ & $\begin{array}{c}\text { HIV+ } \\
(n=33,48.5 \%)\end{array}$ & $\begin{array}{l}\text { Odds Ratio } \\
(95 \% \mathrm{Cl})\end{array}$ & p-value ${ }^{\#}$ \\
\hline \multicolumn{6}{|l|}{ Demographics } \\
\hline Age years, median (IQR) & $50.5(38-63.5)$ & $62(47-66)$ & $41(36-56)$ & - & $0.003^{*}$ \\
\hline Male sex, n (\%) & $25(36.8)$ & $12(34.3)$ & $13(39.4)$ & $\begin{array}{c}1.2 \\
(0.5-3.3)\end{array}$ & 0.80 \\
\hline Current smoker, n (\%) & $2(2.9)$ & $1(2.9)$ & $1(3.0)$ & $\begin{array}{c}1.1 \\
(<0.1->10)\end{array}$ & $>0.99$ \\
\hline \multicolumn{6}{|l|}{ Comorbidity, n (\%) } \\
\hline Hypertension & $26(38.2)$ & $18(51.4)$ & $8(24.2)$ & $\begin{array}{c}0.3 \\
(0.1-0.8)\end{array}$ & 0.026 \\
\hline Diabetes & $17(25.0)$ & $13(37.1)$ & $4(12.1)$ & $\begin{array}{c}0.2 \\
(0.1-0.8)\end{array}$ & 0.025 \\
\hline Obesity $^{\$}, n=57$ & $23(40.4)$ & $11(31.4)$ & $12(36.4)$ & $\begin{array}{c}1.8 \\
(0.6-5.1)\end{array}$ & 0.42 \\
\hline Active TB & $6(8.8)$ & $1(2.9)$ & $5(15.2)$ & $\begin{array}{c}6.1 \\
(0.9->10)\end{array}$ & 0.10 \\
\hline History TB & $16(23.5)$ & $2(5.7)$ & $14(42.4)$ & $\begin{array}{c}12.2 \\
(2.7->10)\end{array}$ & $<0.001$ \\
\hline \multicolumn{6}{|l|}{ HIV associated parameters } \\
\hline HIV viremic, $n$ (\% of all HIV) & - & - & $9(27.3)$ & - & - \\
\hline Years ART, median (IQR) & - & - & $11.6(6.1-13.3)$ & - & - \\
\hline $\begin{array}{c}\text { CD4 cells } / \mu \mathrm{L}, \\
\text { median (IQR) } n=65\end{array}$ & $309(170-545)$ & $339(227-592)$ & $277(134-461)$ & - & $0.072^{*}$ \\
\hline \multicolumn{6}{|l|}{ COVID-19 treatment, n (\%) } \\
\hline Corticosteroids & $43(63.2)$ & $25(71.4)$ & $18(54.5)$ & $\begin{array}{c}0.5 \\
(0.2-1.3)\end{array}$ & 0.21 \\
\hline Anticoagulants & $31(45.6)$ & $18(51.4)$ & $13(39.4)$ & $\begin{array}{c}0.6 \\
(0.2-1.6)\end{array}$ & 0.34 \\
\hline
\end{tabular}

number of PLWH participants requiring supplemental oxygen more than doubled from $24 \%$ to $57 \%$ $(\mathrm{p}=0.0025$, Figure 1A).

To examine whether the differences in the requirement for supplemental oxygen in PLWH were because of differences in the level of HIV control between waves, we examined the fraction of timepoints where participants showed HIV viremia (we excluded low level viremia of unclear significance and set the threshold at $\mathrm{VL}_{\llcorner} 200$ copies/ml [70]). Furthermore, we determined whether ART was detectable in the blood by LC-MS/MS. Second wave participants had approximately 2-fold higher fraction of timepoints where HIV viremia was detected (Figure 1B). In agreement with this, the fraction of participants with no detectable ART in the blood was also about 2-fold higher (Figure 1C). These observations are consistent with diminished suppression of HIV in second wave PLWH enrolled in this study. The specific HIV regimen had no discernible effect on disease severity (Figure 1-figure supplement 1).

We compared comorbidities and other characteristics between the PLWH and HIV negative participants on supplemental oxygen (Table 2). Strikingly, the median age of PLWH on supplemental oxygen was 21 years younger relative to HIV negative (41 versus $62, \mathrm{p}=0.003$ ). PLWH had significantly lower frequency of comorbidities which are usually associated with more severe COVID-19 disease: both hypertension $(\mathrm{p}=0.03)$ and diabetes $(\mathrm{p}=0.03)$ were lower. In contrast, the median CD4 T cell count across all study visits was lower in PLWH (277 versus 339) although this difference did not reach statistical significance $(\mathrm{p}=0.07)$. There was no significant difference in the fraction of participants treated with corticosteroids $(\mathrm{p}=0.2)$.

Interestingly, when comparing HIV negative participants requiring supplemental oxygen to those 
with not requiring supplemental oxygen (Supplementary File 6), those on supplemental oxygen were significantly older (62 versus 47 years, $\mathrm{p}=0.002$ ), and had significantly higher frequency of hypertension $(\mathrm{p}=0.002)$ and diabetes $(\mathrm{p}=0.02)$. This differed from PLWH, where differences in age and comorbidities were not significant between PLWH requiring supplemental oxygen and those not (Supplementary File $7)$, although there was a trend to a higher frequency for hypertension $(\mathrm{p}=0.1)$.

HIV viremic participants showed lower CD4 counts relative to HIV suppressed or HIV negative participants (Figure 1-figure supplement 2). Surprisingly, there was no difference in either the fraction of HIV viremic timepoints or fraction of timepoints where ART was not detected in the blood between the supplemental oxygen and no supplemental oxygen groups (Figure 1-figure supplement 3). We also analyzed the time of SARS-CoV-2 clearance as a function of CD4 count and HIV status and found that while a participants with a low CD4 count $(<200)$ showed a trend of longer time to SARS-CoV-2 clearance $(\mathrm{p}=0.11)$, HIV viremia had no effect (Figure 1-figure supplement 4). Hence, while the PLWH enrolled in the second wave had both worse control of HIV infection and had a higher fraction requiring supplemental oxygen, we did not observe that the PLWH requiring supplemental oxygen had a higher frequency of HIV viremia.

\section{SARS-CoV-2 has differential effects on CD4 count and the neutrophil to lymphocyte ratio between infection waves in PLWH}

We next determined whether the increased disease severity in PLWH in infection wave 2 was reflected in the cellular immune response to SARS-CoV-2 infection. We therefore examined the CD4 count and NLR, both known to be strongly associated with disease severity. We used a 3-point scale for disease severity, where 1: asymptomatic, 2: mild, and 3: supplemental oxygen (at any point in the study) or death. Death was merged with supplemental oxygen because of the small number of participants who died, and was not excluded in any of the subsequent analyses.

As expected, we observed a significant decrease in CD4 T cell count at the highest severity which included disease that required administration of supplemental oxygen and/or resulted in death (Figure 2A, see Figure 2-figure supplement 1 for all data points and number of data points per graph).

We then asked whether PLWH in infection wave 2 showed different CD4 responses to SARS-CoV-2. Since decreased CD4 count could be due to HIV infection alone, we separated the data into timepoints when SARS-CoV-2 was detectable by qPCR and after it was cleared. Upon SARS-CoV-2 clearance, the immune response of convalescent participants should start the return to baseline, and differences due to SARS-CoV-2 should decrease and reflect HIV mediated effects only.

The CD4 counts in PLWH in infection wave 2 were lower during active SARS-CoV-2 infection relative to wave 1 (Figure $2 \mathrm{~B}$, median 172 versus 420 cells/ $\mu \mathrm{L}$, a decrease of 2.4 -fold) and were below the 200 cells $/ \mu \mathrm{L}$ clinically used threshold indicating a low CD4 count. However, CD4 counts for PLWH for both wave 2 and wave 1 recovered post-SARS-CoV-2 clearance ( 408 for wave 2 versus 584 cells/ $\mu \mathrm{L}$ for wave 1), consistent the low CD4 count in PLWH in wave 2 being SARS-CoV-2 induced. CD4 counts for both groups were substantially above the 200 cells $/ \mu \mathrm{L}$ threshold after SARS-CoV-2 clearance. HIV negative participants showed no or minor differences in CD4 counts between waves, although these minor differences showed significance due to the large number of participant timepoints for this group (Figure $2 \mathrm{C})$. 
A

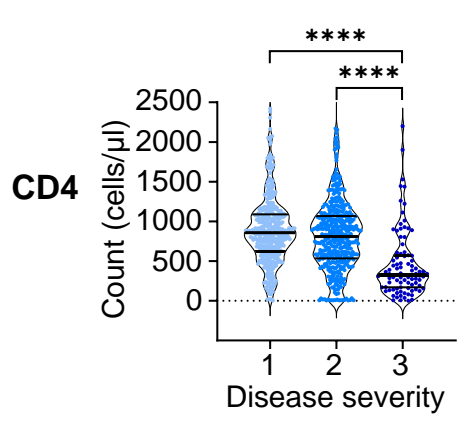

D

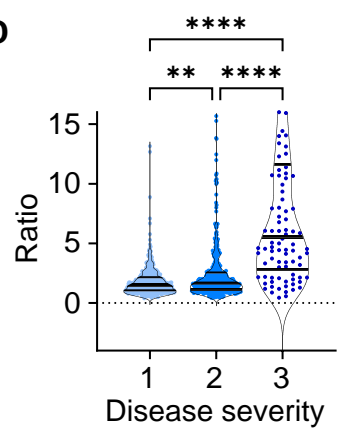

B

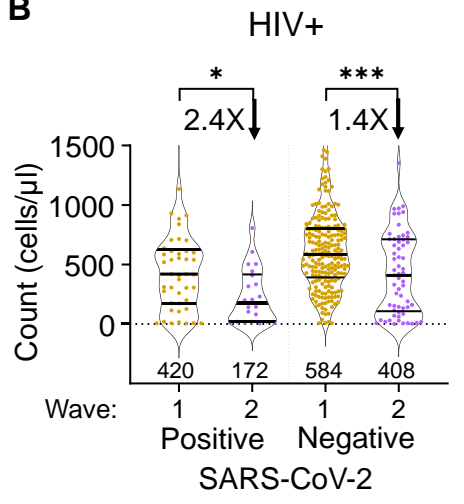

E

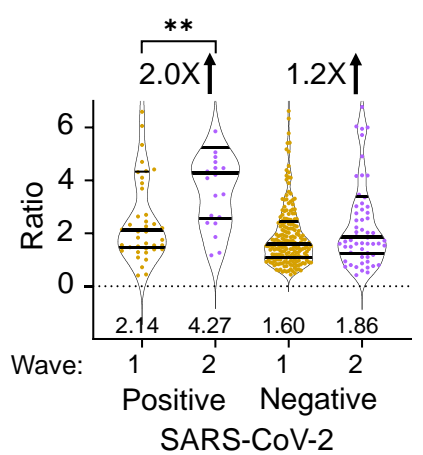

C

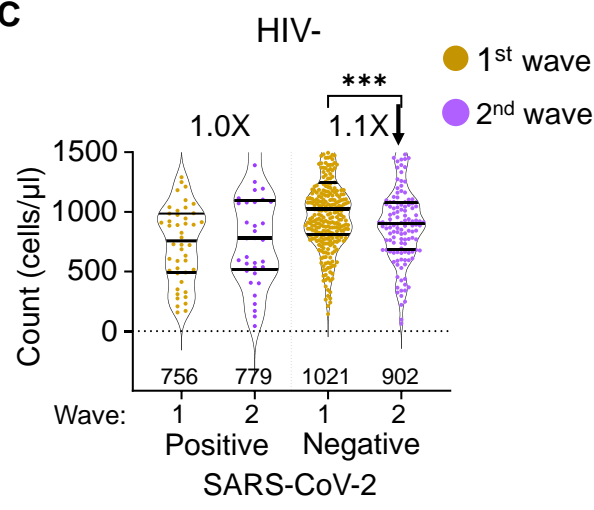

$\mathbf{F}$

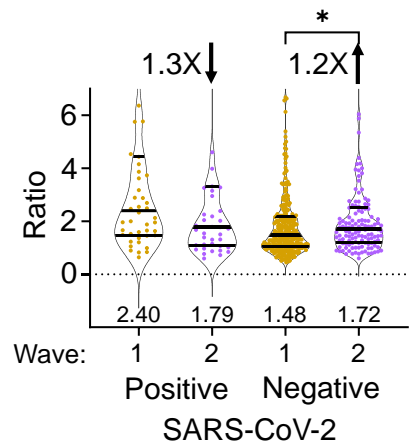

Figure 2: The differential effect of HIV on the CD4 count and neutrophil to lymphocyte ratio between waves. (A) The concentration of CD4 T cells in the blood in all participants in all infection waves and at all timepoints as a function of disease severity. Disease severity was scored as 1: asymptomatic, 2: mild, and 3: on supplemental oxygen or death. CD4 counts in PLWH (B) and HIV negative (C) participants in waves 1 versus waves 2 during active SARS-CoV-2 infection and after SARS-CoV-2 clearance. (D) Neutrophil to lymphocyte ratio (NLR) in the blood in all participants in all infection waves and at all timepoints as a function of disease severity. NLR in PLWH (E) and HIV negative (F) participants in waves 1 versus waves 2 during active SARS-CoV-2 infection and after SARS-CoV-2 clearance. SARS-CoV-2 positive indicates a timepoint where SARS-CoV-2 RNA was detected. Data shown as violin plots with median and IQR, with the median denoted below each plot. Fold-change in the second wave versus first wave is indicated, with arrow denoting direction of change. p-values are ${ }^{*}<0.05 ;{ }^{* *}<0.01 ; * * *<0.001,{ }^{* * * *}<0.0001$ as determined by Kruskal-Wallis test with Dunn's multiple comparison correction or by Mann-Whitney U test. Plots scales were restricted to highlight changes close to the median. See Fig.S6 for complete plots and the number of data points per plot.

The NLR had a remarkably similar pattern. An elevated NLR associated strongly with higher disease severity (Figure 2D). PLWH with active SARS-CoV-2 infection in wave 2 showed a 2 -fold increase in the NLR relative to PLWH with active SARS-CoV-2 infection in wave 1 (Figure 2E). This difference declined to 1.2-fold once SARS-CoV-2 was cleared, consistent with differences in NLR being SARS-CoV-2 driven and not a result of other pathology in PLWH in wave 2. In contrast, the NLR was lower in HIV negative participants in wave 2 relative to wave 1 in the presence of SARS-CoV-2 (Figure 2F).

The observed recovery of the CD4 count may result from improved access to ART due to the hospital visit in wave 2 . We therefore checked whether the fraction of HIV viremic participants decreased upon convalescence and whether there was an associated decrease in the number of PLWH with undetectable ART. We observed no significant differences in either viremia or fraction of PLWH with undetectable ART in either wave between timepoints which were SARS-CoV-2 positive and those that were negative (Figure 2-figure supplement 2). This indicates that the increase in the CD4 was not due to better linkage to care after the hospital visit but rather due to SARS-CoV-2 clearance. 


\section{Differences in the frequencies and associations of immune cell subsets in PLWH and HIV negative participants}

To examine differences in immune cell subset associations between HIV negative and PLWH participant groups, we conducted detailed phenotyping of immune cells using longitudinal fresh PBMC samples and correlated these to measured phenotypes and clinical parameters in both HIV negative and PLWH groups (Figure 3; see Figure 3-figure supplement 1 for gating strategies). We used established approaches for gating of cell subsets [71] and [72]. This was only performed for the first wave participants, where cells were available for additional phenotyping by flow cytometry.

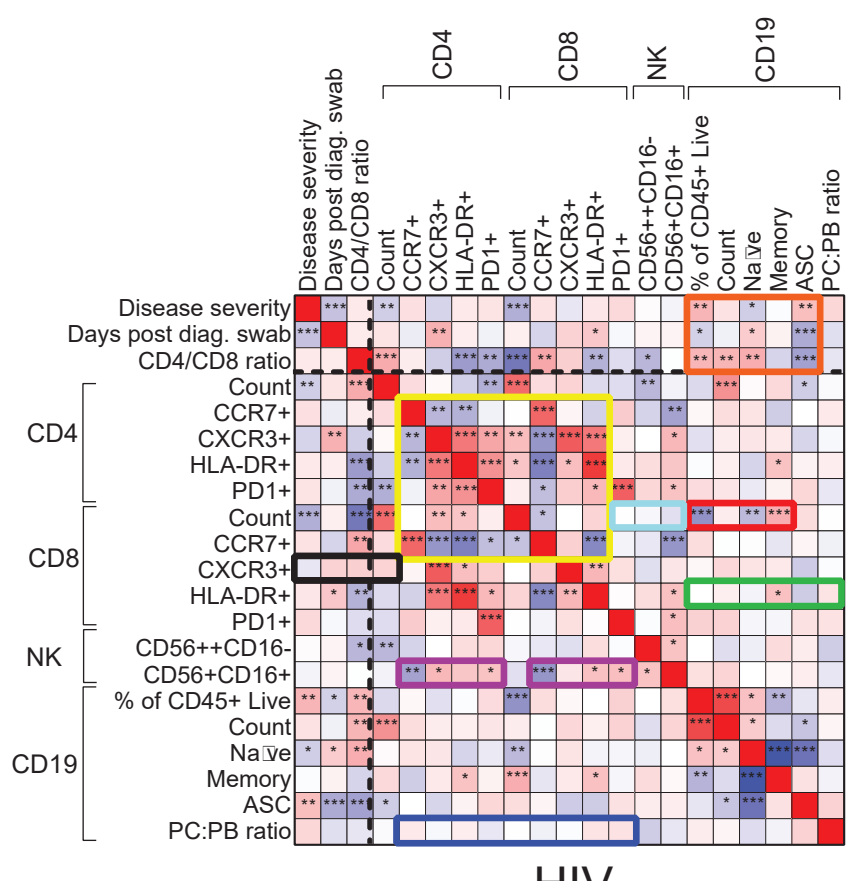

HIV-

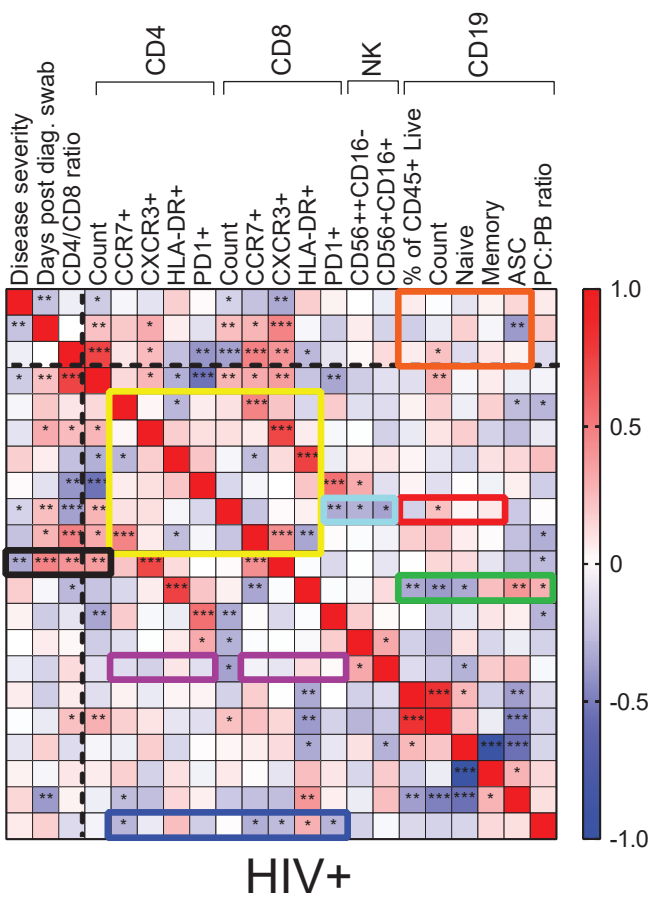

Figure 3: Immune cell and clinical correlates in HIV negative and PLWH groups. Spearman rank correlation values $(\rho)$ are shown from red (1.0) to blue (-1.0). p-values per correlation are ${ }^{*}<0.5 ;{ }^{* *}<0.01 ;{ }^{* * *}<$ 0.001. The number of matched pairs for HIV negative participants ranged from 77 to 229 and for PLWH from 48 to 164. Rectangles represent regions where a set of correlations is present in one group and absent in the other. Black dashed lines represent the divide between clinical and cellular parameters.

For HIV negative participants, there were significant negative and positive correlations between CD4 T cell parameters, and between these and the CD8 T cell count and phenotypes (Figure 3, yellow box). There were negative correlations between CD4 and the CD8 CCR7+ T cell phenotype and CD56+CD16+ NK cells (purple box). The fraction of NK cells positively correlated with the CXCR3 fraction of CD4 T cells, with HLA-DR on CD8 T cells, and with PD-1 on both cell types (purple box). In addition, there were correlations between CD8 T cell count and CD19 B cell parameters, such as fractions of naïve and memory B cells (red box). Interestingly, disease severity as well as the CD4/CD8 ratio showed correlations with B cell parameters, including the frequency of antibody secreting cells (ASC), which were lost in PLWH (orange box).

New correlations arose in PLWH, particularly involving CD8 T cells: CXCR3+ CD8 T cells were negatively correlated with disease severity but positively correlated with the CD4/CD8 ratio and the CD4 T cell count (Figure 3, black box). CD8 T cell activation (HLA-DR+) was correlated with several CD19+ B cell phenotypes (green box), and the plasma cell to plasmablast ratio, determined by CD138 expression, correlated with both CD4 and CD8 T cell phenotypes (blue box). In addition, CD8 T cell count showed negative correlations with CD8 PD-1 and NK cell phenotypes only in PLWH (turquoise 


\section{A}
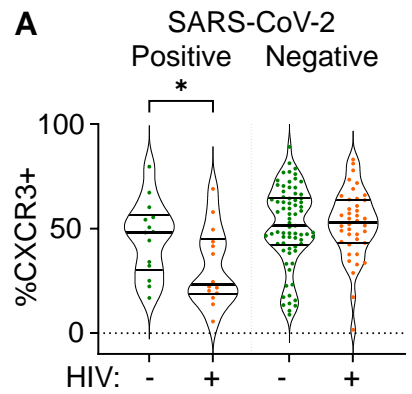

C
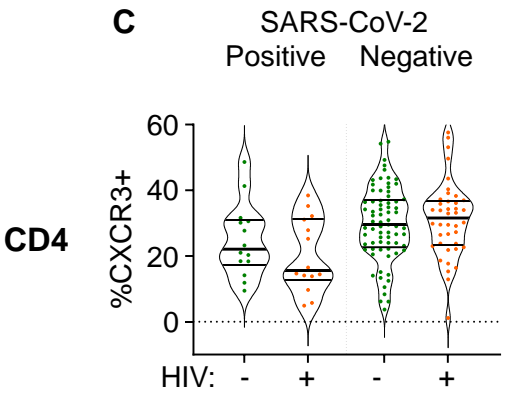
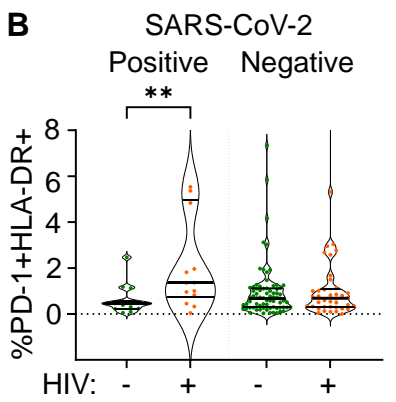

D

SARS-CoV-2

Positive Negative

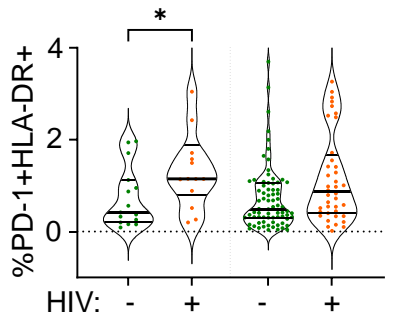

Figure 4: Differences between PLWH and HIV negative participants in immune cell markers. Percent of CD8 T cells positive for CXCR3 (A) or double positive for HLA-DR and PD-1 (B). Percent of CD4 T cells positive for CXCR3 (C) or double positive for HLA-DR and PD-1 (D). Data is composed of 15 participant timepoints which were SARS-CoV-2+HIV-, 14 SARS-CoV-2+HIV+, 40 SARS-CoV-2-HIV+ and 74 SARS-CoV-2-HIV-, where SARS-CoV-2+ indicates SARS-CoV-2 RNA was detected in the upper respiratory tract. p-values for differences between PLWH and HIV negative participants are ${ }^{*}<0.05 ;^{* *}<0.01 ;{ }^{* * *}<0.001$, $* * * *<0.0001$ as determined by the Mann-Whitney $\mathrm{U}$ test.

\section{Discussion}

We observed that in our cohort, COVID-19 disease severity was higher in PLWH, consistent with some of the larger epidemiological studies [33-38], although in this study differences were detected in the frequency of participants requiring supplemental oxygen and not in mortality. Our cohort may not be a typical 'hospitalized cohort' as the majority of participants did not require supplemental oxygen. We therefore cannot discern effects of HIV on critical SARS-CoV-2 cases since these numbers are too small in the cohort. However, focusing on lower disease severity enabled us to capture a broader range of outcomes which predominantly ranged from asymptomatic to requiring supplemental oxygen. Understanding this part of the disease spectrum could be important since it may indicate underlying changes in the immune response which affect long-term quality of life and response to vaccines. 
A higher fraction of PLWH requiring supplemental oxygen relative to HIV negative participants was driven by SARS-CoV-2 infections in the second, $\beta$ variant dominated SARS-CoV-2 infection wave in South Africa. The odds ratio for requiring supplemental oxygen in the second wave for PLWH was 4.0 relative to HIV negative participants. The $95 \%$ confidence intervals were wide at 1.6-10.4, reflecting the relatively small number of participants. However, confidence intervals did not overlap one.

Consistent with HIV infection leading to more severe SARS-CoV-2 infection outcomes in our study is the much younger age of PLWH requiring supplemental oxygen relative to HIV negative participants (41 versus 63 years). PLWH on supplemental oxygen also had lower frequencies of hypertension and diabetes. Age, hypertension, and diabetes are risk factors for more severe COVID-19 disease [38, 76-78], and their absence may indicate that the more severe outcome is driven by another factor, with HIV infection being the simplest explanation.

The cause of the difference between waves in PLWH may be because PLWH enrolled in the second infection wave had worse suppression of HIV with ART: both the fractions of timepoints where viremia was detected and where ART was absent were about 2-fold higher and indeed were very high at about $40 \%$. We therefore expected that this showed a direct link between HIV viremia and the requirement for supplemental oxygen during COVID-19 disease in PLWH. However, there was no difference in the frequency of viremia between those requiring supplemental oxygen and those not.

Furthermore, the substantial recovery of CD4 T cell counts in PLWH after SARS-CoV-2 clearance in wave 2 may be consistent with the $\beta$ variant having more impact on the CD4 count relative to the ancestral SARS-CoV-2 strain infections in the first wave. A similar pattern was seen in the NLR, which was higher in wave 2 relative to wave 1 in PLWH with active SARS-CoV-2 infection, but then decreased to similar levels upon convalescence. The role of the $\beta$ variant is supported by data showing extensive evolution, increasing the ability of $\beta$ to escape the interferon response and result in more efficient viral cell-to-cell transmission [63-65]. $\beta$ variant hospitalizations also led to more deaths in South Africa [61]. Therefore, the effect of the variant on PLWH in addition to HIV suppression status should be considered.

Our data detailing the SARS-CoV-2 response of more defined immune cell subsets in PLWH versus HIV negative participants is limited by the data only being available for the first infection wave. However, even in samples from that wave, there were multiple differences in correlations between cell subsets in PLWH relative to HIV negative participants, which may be another indication of differences in the immune response to SARS-CoV-2. We cannot deduce from these associations whether the differences could have an impact on disease severity. However, the fraction of CXCR3+ CD8 T cells decreased in the blood compartment and PD-1+HLA-DR+ CD8 and CD4 T cells increased. The increase in PD-1+HLA$\mathrm{DR}+\mathrm{T}$ cells indicates $\mathrm{T}$ cell activation [73, 74] which associates with worse COVID-19 outcomes [79]. CXCR3 plays a key role in $\mathrm{T}$ cell homing to sites of inflammation and is activated by interferon-inducible ligands CXCL9, CXCL11, and CXCL10 (IP-10) [75, 80]. A decrease in CXCR3 indicates either that T cells are less able to home to the site of infection, or that there is more inflammation in PLWH during SARS-CoV-2 infection and therefore more homing of the CXCR3+ CD8 T cells to tissues so that the fraction of CXCR3 + cells left in the blood decreases. Either way, the combination of these changes likely indicates either more pronounced SARS-CoV-2 infection or an impaired response in PLWH despite the similar infection outcomes in this wave.

In summary, PLWH showed increased disease severity mostly restricted to the second infection wave, where the $\beta$ variant was dominant. Increased severity was associated with low CD4 T cell counts and high NLR which stabilized post-SARS-CoV-2 clearance in second wave infected PLWH to close to wave 1 PLWH values, arguing for a synergy between SARS-CoV-2 and HIV to decrease CD4 T cell numbers and increase the NLR rather than the status of HIV infection alone determining these parameters. More work is required to understand how these HIV related immune perturbations influence long-term immunity to SARS-CoV-2 infection and whether vaccine response will be affected. 


\section{Material and Methods}

\section{Ethical statement and study participants}

The study protocol was approved by the University of KwaZulu-Natal Institutional Review Board (approval BREC/00001275/2020). Adult patients (>18 years old) presenting at King Edward VIII, Inkosi Albert Luthuli Central, or Clairwood Hospitals in Durban, South Africa, between 8 June to 25 September 2020, diagnosed to be SARS-CoV-2 positive as part of their clinical workup and able to provide informed consent were eligible for the study. Written informed consent was obtained for all enrolled participants.

\section{Clinical laboratory testing}

An HIV rapid test and viral load quantification was performed from a 4ml EDTA tube of blood at an accredited diagnostic laboratory (Molecular Diagnostic Services, Durban, South Africa) using the RealTime HIV negative1 viral load test on an Abbott machine. CD4 count, CD8 count, and a full blood count panel were performed by an accredited diagnostic laboratory (Ampath, Durban, South Africa). Depending on the volume of blood which was drawn, the CD8, CD4, and full blood count was not available for every participant, and numbers performed are detailed in the figure legends.

\section{qPCR detection of SARS-CoV-2}

RNA was extracted from combined oropharyngeal and nasophryngeal swabs from $140 \mu \mathrm{l}$ viral transport medium using the QIAamp Viral RNA Mini kit (cat. no. 52906, QIAGEN, Hilden, Germany) according to manufacturer's instructions, and eluted into $100 \mu \mathrm{l}$ AVE buffer. To detect SARS-CoV-2 RNA, $5 \mu \mathrm{l}$ RNA was added to the TaqPath 1-step RT-qPCR mastermix. 3 SARS-CoV-2 genes (ORF1ab, S and N) were amplified using the TaqPath COVID-19 Combo Kit and TaqPath COVID-19 CE-IVD RT-PCR Kit (ThermoFisher Scientific, Massachusetts, United States) in a QuantStudio 7 Flex Real-Time PCR system (ThermoFisher Scientific). Data was analysed using the Design and Analysis software (ThermoFisher Scientific). For positive samples, $\mathrm{Ct}$ values are represented as the average of the $\mathrm{Ct}$ values of all three genes. A sample was scored positive where at least 2 out of the 3 genes were detected, and inconclusive if only 1 of the genes was detected.

\section{PBMC isolation and immune phenotyping by flow cytometry}

PBMCs were isolated by density gradient centrifugation using Histopaque 1077 (Sigma-Aldrich, St. Louis, Missouri, United States) and SepMate separation tubes (STEMCELL Technologies, Vancouver, Canada). For T cell and NK cell phenotyping, $10^{6}$ fresh PBMCs were surface stained in 501 antibody mix with the following antibodies from BD Biosciences (Franklin Lakes, NJ, USA): anti-CD45 Hv500 (1:100 dilution, clone HI30, cat. 560777); anti-CD8 BV395 (1:50 dilution, clone RPA-T8, cat. 563795); anti-CD4 BV496 (1:25 dilution, clone SK3, cat. 564651); anti-PD1 BV421 (1:50 dilution, clone EH12.1, cat. 562516); anti-CXCR3 PE-CF594 (1:25 dilution, clone 1C6/CXCR3, cat. 562451). The following antibodies were from BioLegend (San Diego, CA, USA): anti-CD19 Bv605 (1:100 dilution, clone HIB19, cat. 302244); anti-CD16 Bv650 (1:50 dilution, clone 3G8, cat. 302042); anti-CD56 Bv711 (1:50 dilution, clone HCD56, cat. 318336); anti-CD3 Bv785 (1:25 dilution, clone OKT3, cat. 317330); anti-CXCR5 FITC (1:25 dilution, clone J252D4, cat. 356914); anti-HLA-DR PE (1:50 dilution, clone L243, cat. 307606); anti-CCR7 PerCP-Cy5.5 (1:25 dilution, clone G043H7, cat. 353220); anti-CD38 PE-Cy7 (1:25 dilution, clone HIT2, cat. 303516); anti-ICOS APC (1:25 dilution, clone C398.4A, cat. 313510) and anti-CD45RA AF700 (1:25 dilution, clone HI100, cat. 304120). PBMCs were incubated with antibodies for 20 minutes at room temperature. For B-cell phenotyping, the following antibodies were used: (all from BioLegend) anti-CD45 APC (1:25 dilution, clone HI30, cat. 304012); anti-CD3 Bv711 (1:50 dilution, clone OKT3, cat. 317328), anti-CD14 Bv711 (1:25 dilution, clone M5E2, cat. 301838); anti-CD19 Bv605 (1:50 dilution, clone HIB19, cat. 302244); anti-CD27 Hv500 (1:50 dilution, clone O323, cat. 302836); anti-CD38 PE-Cy7 (1:25 dilution, clone HIT2, cat. 303516) and anti-CD138 BV785 (1:25 dilution, clone MI15, cat. 356538). Cells were then washed twice in PBS and fixed in $2 \%$ paraformaldehyde and 
stored at $4^{\circ} \mathrm{C}$ before acquisition on FACSAria Fusion III flow cytometer (BD) and analysed with FlowJo software version 9.9.6 (Tree Star). Depending on the volume of blood which was drawn, full phenotyping was only available for participants where sufficient blood was available for the assay.

\section{Statistical analysis}

Data is described with the non-parametric measures of median and interquartile range, and significance determined using the non-parametric Mann-Whitney U test for pairwise comparisons, Fisher Exact test for pairwise comparisons of frequencies, and the Kruskal-Wallis test with multiple comparison correction by the Dunn Method for comparisons involved more than two populations. All tests were performed using Graphpad Prism 8 or Stata software.

\section{Acknowledgements}

This work was supported by the Bill and Melinda Gates Investment INV-018944 to AS.

\section{COMMIT-KZN Team}

Moherndran Archary, Department of Paediatrics and Child Health, University of KwaZulu-Natal Kaylesh J. Dullabh, Department of Cardiothoracic Surgery, University of KwaZulu-Natal Jennifer Giandhari, KwaZulu-Natal Research Innovation and Sequencing Platform Philip Goulder, Africa Health Research Institute and Department of Paediatrics, Oxford Guy Harling, Africa Health Research Institute and the Institute for Global Health, University College London

Rohen Harrichandparsad, Department of Neurosurgery, University of KwaZulu-Natal Kobus Herbst, Africa Health Research Institute and the South African Population Research Infrastructure Network

Prakash Jeena, Department of Paediatrics and Child Health, University of KwaZulu-Natal Thandeka Khoza, Africa Health Research Institute

Nigel Klein, Africa Health Research Institute and the Institute of Child Health, University College London

Richard Lessells, KwaZulu-Natal Research Innovation and Sequencing Platform

Rajhmun Madansein, Department of Cardiothoracic Surgery, University of KwaZulu-Natal

Mohlopheni Marakalala, Africa Health Research Institute and Division of Infection and Immunity, University College London

Mosa Moshabela, College of Health Sciences, University of KwaZulu-Natal

Kogie Naidoo, Centre for the AIDS Programme of Research in South Africa

Zaza Ndhlovu, Africa Health Research Institute and the Ragon Institute of MGH, MIT and Harvard Kennedy Nyamande, Department of Pulmonology and Critical Care, University of KwaZulu-Natal Nesri Padayatchi, Centre for the AIDS Programme of Research in South Africa

Vinod Patel, Department of Neurology, University of KwaZulu-Natal

Theresa Smit, Africa Health Research Institute

Adrie Steyn, Africa Health Research Institute and Division of Infectious Diseases, University of Alabama at Birmingham

\section{References}

1. Kharsany, A. B., Cawood, C., Khanyile, D., Lewis, L., Grobler, A., Puren, A., Govender, K., George, G., Beckett, S. \& Samsunder, N. Community-based HIV prevalence in KwaZulu-Natal, South Africa: results of a cross-sectional household survey. The Lancet HIV 5, e427-e437. ISSN: 2352-3018 (2018). 
2. Tegally, H., Wilkinson, E., Lessells, R. R., Giandhari, J., Pillay, S., Msomi, N., Mlisana, K., Bhiman, J., Allam, M., Ismail, A., Engelbrecht, S., Van Zyl, G., Preiser, W., Williamson, C., Pettruccione, F., Sigal, A., Gazy, I., Hardie, D., Hsiao, M., Martin, D., York, D., Goedhals, D., San, E. J., Giovanetti, M., Lourenco, J., Alcantara, L. C. J. \& de Oliveira, T. Major new lineages of SARSCoV-2 emerge and spread in South Africa during lockdown. medRxiv, 2020.10.28.20221143. https: //www . medrxiv . org/content/medrxiv/early/2020/10/30/2020 .10.28.20221143. full . pdf (2020).

3. Tegally, H., Wilkinson, E., Giovanetti, M., Iranzadeh, A., Fonseca, V., Giandhari, J., Doolabh, D., Pillay, S., San, E. J., Msomi, N., Mlisana, K., von Gottberg, A., Walaza, S., Allam, M., Ismail, A., Mohale, T., Glass, A. J., Engelbrecht, S., Van Zyl, G., Preiser, W., Petruccione, F., Sigal, A., Hardie, D., Marais, G., Hsiao, M., Korsman, S., Davies, M.-A., Tyers, L., Mudau, I., York, D., Maslo, C., Goedhals, D., Abrahams, S., Laguda-Akingba, O., Alisoltani-Dehkordi, A., Godzik, A., Wibmer, C. K., Sewell, B. T., Lourenço, J., Alcantara, L. C. J., Pond, S. L. K., Weaver, S., Martin, D., Lessells, R. J., Bhiman, J. N., Williamson, C. \& de Oliveira, T. Emergence and rapid spread of a new severe acute respiratory syndrome-related coronavirus 2 (SARS-CoV-2) lineage with multiple spike mutations in South Africa. medRxiv, 2020.12.21.20248640. https: //www . medrxiv . org/content/medrxiv/early/2020/12/22/2020.12 .21.20248640. full . pdf (2020).

4. Dalgleish, A. G., Beverley, P. C., Clapham, P. R., Crawford, D. H., Greaves, M. F. \& Weiss, R. A. The CD4 (T4) antigen is an essential component of the receptor for the AIDS retrovirus. Nature 312, 763-767 (1984).

5. Westendorp, M. O., Frank, R., Ochsenbauer, C., Stricker, K., Dhein, J., Walczak, H., Debating, K.-M. \& Krammer, P. H. Sensitization of T cells to CD95-mediated apoptosis by HIV-1 Tat and gp120. Nature 375, 497-500 (1995).

6. Doitsh, G., Cavrois, M., Lassen, K. G., Zepeda, O., Yang, Z., Santiago, M. L., Hebbeler, A. M. \& Greene, W. C. Abortive HIV infection mediates CD4 T cell depletion and inflammation in human lymphoid tissue. Cell 143, 789-801. ISSN: 1097-4172 (Electronic) 0092-8674 (Linking). http://www.ncbi.nlm.nih.gov/pubmed/21111238 (2010).

7. Doitsh, G., Galloway, N. L., Geng, X., Yang, Z., Monroe, K. M., Zepeda, O., Hunt, P. W., Hatano, H., Sowinski, S., Munoz-Arias, I. \& Greene, W. C. Cell death by pyroptosis drives CD4 T-cell depletion in HIV-1 infection. Nature 505, 509-14. ISSN: 1476-4687 (Electronic) 0028-0836 (Linking). http://www.ncbi.nlm.nih.gov/pubmed/24356306 (2014).

8. Jackson, L., Hunter, J., Cele, S., Ferreira, I. M., Young, A. C., Karim, F., Madansein, R., Dullabh, K. J., Chen, C.-Y., Buckels, N. J., Ganga, Y., Khan, K., Boulle, M., Lustig, G., Neher, R. A. \& Sigal, A. Incomplete inhibition of HIV infection results in more HIV infected lymph node cells by reducing cell death. eLife 7, e30134 (2018).

9. Okoye, A. A. \& Picker, L. J. CD 4+ T-cell depletion in HIV infection: mechanisms of immunological failure. Immunological reviews 254, 54-64 (2013).

10. Pallikkuth, S., Parmigiani, A., Silva, S. Y., George, V. K., Fischl, M., Pahwa, R. \& Pahwa, S. Impaired peripheral blood T-follicular helper cell function in HIV-infected nonresponders to the 2009 H1N1/09 vaccine. Blood, The Journal of the American Society of Hematology 120, 985-993 (2012).

11. Perreau, M., Savoye, A.-L., De Crignis, E., Corpataux, J.-M., Cubas, R., Haddad, E. K., De Leval, L., Graziosi, C. \& Pantaleo, G. Follicular helper T cells serve as the major CD4 T cell compartment for HIV-1 infection, replication, and production. Journal of Experimental Medicine 210, 143-156 (2013).

12. Moir, S. \& Fauci, A. S. Insights into B cells and HIV-specific B-cell responses in HIV-infected individuals. Immunological reviews 254, 207-224 (2013). 
13. Day, C. L., Kaufmann, D. E., Kiepiela, P., Brown, J. A., Moodley, E. S., Reddy, S., Mackey, E. W., Miller, J. D., Leslie, A. J., DePierres, C., et al. PD-1 expression on HIV-specific T cells is associated with T-cell exhaustion and disease progression. Nature 443, 350-354 (2006).

14. Deeks, S. G., Kitchen, C. M., Liu, L., Guo, H., Gascon, R., Narváez, A. B., Hunt, P., Martin, J. N., Kahn, J. O., Levy, J., et al. Immune activation set point during early HIV infection predicts subsequent CD4+ T-cell changes independent of viral load. Blood 104, 942-947 (2004).

15. Mavigner, M., Cazabat, M., Dubois, M., L'Faqihi, F.-E., Requena, M., Pasquier, C., Klopp, P., Amar, J., Alric, L., Barange, K., et al. Altered CD4+ T cell homing to the gut impairs mucosal immune reconstitution in treated HIV-infected individuals. The Journal of clinical investigation 122, 62-69 (2012).

16. Lucas, C., Wong, P., Klein, J., Castro, T. B., Silva, J., Sundaram, M., Ellingson, M. K., Mao, T., Oh, J. E., Israelow, B., et al. Longitudinal analyses reveal immunological misfiring in severe COVID-19. Nature 584, 463-469 (2020).

17. Sekine, T., Perez-Potti, A., Rivera-Ballesteros, O., Strålin, K., Gorin, J.-B., Olsson, A., LlewellynLacey, S., Kamal, H., Bogdanovic, G., Muschiol, S., et al. Robust T cell immunity in convalescent individuals with asymptomatic or mild COVID-19. Cell (2020).

18. Chen, G., Wu, D., Guo, W., Cao, Y., Huang, D., Wang, H., Wang, T., Zhang, X., Chen, H., Yu, H., et al. Clinical and immunological features of severe and moderate coronavirus disease 2019. The Journal of clinical investigation 130 (2020).

19. Grifoni, A., Weiskopf, D., Ramirez, S. I., Mateus, J., Dan, J. M., Moderbacher, C. R., Rawlings, S. A., Sutherland, A., Premkumar, L. \& Jadi, R. S. Targets of T cell responses to SARS-CoV-2 coronavirus in humans with COVID-19 disease and unexposed individuals. Cell. ISSN: 0092-8674 (2020).

20. Moderbacher, C. R., Ramirez, S. I., Dan, J. M., Grifoni, A., Hastie, K. M., Weiskopf, D., Belanger, S., Abbott, R. K., Kim, C., Choi, J., et al. Antigen-specific adaptive immunity to SARS-CoV-2 in acute COVID-19 and associations with age and disease severity. Cell (2020).

21. Mathew, D., Giles, J. R., Baxter, A. E., Oldridge, D. A., Greenplate, A. R., Wu, J. E., Alanio, C., Kuri-Cervantes, L., Pampena, M. B., D'Andrea, K., et al. Deep immune profiling of COVID-19 patients reveals distinct immunotypes with therapeutic implications. Science 369 (2020).

22. Mateus, J., Grifoni, A., Tarke, A., Sidney, J., Ramirez, S. I., Dan, J. M., Burger, Z. C., Rawlings, S. A., Smith, D. M., Phillips, E., et al. Selective and cross-reactive SARS-CoV-2 T cell epitopes in unexposed humans. Science 370, 89-94 (2020).

23. Liao, M., Liu, Y., Yuan, J., Wen, Y., Xu, G., Zhao, J., Cheng, L., Li, J., Wang, X., Wang, F., et al. Single-cell landscape of bronchoalveolar immune cells in patients with COVID-19. Nature medicine, $1-3(2020)$.

24. Chen, Z. \& Wherry, E. J. T cell responses in patients with COVID-19. Nature Reviews Immunology 20, 529-536 (2020).

25. Woodruff, M. C., Ramonell, R. P., Nguyen, D. C., Cashman, K. S., Saini, A. S., Haddad, N. S., Ley, A. M., Kyu, S., Howell, J. C., Ozturk, T., Lee, S., Suryadevara, N., Case, J. B., Bugrovsky, R., Chen, W., Estrada, J., Morrison-Porter, A., Derrico, A., Anam, F. A., Sharma, M., Wu, H. M., Le, S. N., Jenks, S. A., Tipton, C. M., Staitieh, B., Daiss, J. L., Ghosn, E., Diamond, M. S., Carnahan, R. H., Crowe, J. E., Hu, W. T., Lee, F. E.-H. \& Sanz, I. Extrafollicular B cell responses correlate with neutralizing antibodies and morbidity in COVID-19. Nature Immunology. ISSN: 1529-2916. https://doi.org/10.1038/s41590-020-00814-z (2020).

26. Robbiani, D. F., Gaebler, C., Muecksch, F., Lorenzi, J. C., Wang, Z., Cho, A., Agudelo, M., Barnes, C., Finkin, S., Hagglof, T., et al. Convergent Antibody Responses to SARS-CoV-2 Infection in Convalescent Individuals. bioRxiv (2020). 
27. Quinlan, B. D., Mou, H., Zhang, L., Guo, Y., He, W., Ojha, A., Parcells, M. S., Luo, G., Li, W., Zhong, G., et al. The SARS-CoV-2 receptor-binding domain elicits a potent neutralizing response without antibody-dependent enhancement. IMMUNITY-D-20-00389 (2020).

28. Khoury, D. S., Cromer, D., Reynaldi, A., Schlub, T. E., Wheatley, A. K., Juno, J. A., Subbarao, K., Kent, S. J., Triccas, J. A. \& Davenport, M. P. Neutralizing antibody levels are highly predictive of immune protection from symptomatic SARS-CoV-2 infection. Nat Med. ISSN: 1546-170X (Electronic) 1078-8956 (Linking). https://www.ncbi.nlm.nih.gov/pubmed/34002089 (2021).

29. Earle, K. A., Ambrosino, D. M., Fiore-Gartland, A., Goldblatt, D., Gilbert, P. B., Siber, G. R., Dull, P. \& Plotkin, S. A. Evidence for antibody as a protective correlate for COVID-19 vaccines. Vaccine (2021).

30. Liu, J., Li, S., Liu, J., Liang, B., Wang, X., Wang, H., Li, W., Tong, Q., Yi, J., Zhao, L., et al. Longitudinal characteristics of lymphocyte responses and cytokine profiles in the peripheral blood of SARS-CoV-2 infected patients. EBioMedicine 55, 102763 (2020).

31. Liu, Y., Du, X., Chen, J., Jin, Y., Peng, L., Wang, H. H., Luo, M., Chen, L. \& Zhao, Y. Neutrophilto-lymphocyte ratio as an independent risk factor for mortality in hospitalized patients with COVID-19. Journal of Infection 81, e6-e12 (2020).

32. Zhang, B., Zhou, X., Zhu, C., Song, Y., Feng, F., Qiu, Y., Feng, J., Jia, Q., Song, Q., Zhu, B., et al. Immune phenotyping based on the neutrophil-to-lymphocyte ratio and IgG level predicts disease severity and outcome for patients with COVID-19. Frontiers in molecular biosciences 7, 157 (2020).

33. Boulle, A. et al. Risk factors for COVID-19 death in a population cohort study from the Western Cape Province, South Africa. Clin Infect Dis. IssN: 1537-6591 (Electronic) 1058-4838 (Linking). https://www.ncbi.nlm.nih.gov/pubmed/32860699 (2020).

34. Geretti, A. M., Stockdale, A. J., Kelly, S. H., Cevik, M., Collins, S., Waters, L., Villa, G., Docherty, A., Harrison, E. M., Turtle, L., et al. Outcomes of COVID-19 related hospitalisation among people with HIV in the ISARIC WHO Clinical Characterisation Protocol UK Protocol: prospective observational study (2020).

35. Bhaskaran, K., Rentsch, C. T., MacKenna, B., Schultz, A., Mehrkar, A., Bates, C., Eggo, R. M., Morton, C. E., Bacon, S., Inglesby, P., et al. HIV infection and COVID-19 death: populationbased cohort analysis of UK primary care data and linked national death registrations within the OpenSAFELY platform. medRxiv (2020).

36. Tesoriero, J. M., Swain, C. E., Pierce, J. L., Zamboni, L., Wu, M., Holtgrave, D. R., Gonzalez, C. J., Udo, T., Morne, J. E., Hart-Malloy, R., Rajulu, D. T., Leung, S. J. \& Rosenberg, E. S. COVID-19 Outcomes Among Persons Living With or Without Diagnosed HIV Infection in New York State. JAMA Netw Open 4, e2037069. ISSN: 2574-3805 (Electronic) 2574-3805 (Linking). https://www.ncbi.nlm.nih.gov/pubmed/33533933 (2021).

37. Braunstein, S. L., Lazar, R., Wahnich, A., Daskalakis, D. C. \& Blackstock, O. J. COVID-19 infection among people with HIV in New York City: A population-level analysis of linked surveillance data. Clinical infectious diseases: an official publication of the Infectious Diseases Society of America (2020).

38. Jassat, W., Cohen, C., Tempia, S., Masha, M., Goldstein, S., Kufa, T., Murangandi, P., Savulescu, D., Walaza, S., Bam, J.-L., et al. Risk factors for COVID-19-related in-hospital mortality in a high HIV and tuberculosis prevalence setting in South Africa: a cohort study. The Lancet HIV (2021).

39. Huang, J., Xie, N., Hu, X., Yan, H., Ding, J., Liu, P., Ma, H., Ruan, L., Li, G., He, N., et al. Epidemiological, virological and serological features of COVID-19 cases in people living with HIV in Wuhan City: A population-based cohort study. Clinical Infectious Diseases (2020).

40. Sigel, K., Swartz, T., Golden, E., Paranjpe, I., Somani, S., Richter, F., De Freitas, J. K., Miotto, R., Zhao, S., Polak, P., et al. COVID-19 and people with HIV infection: outcomes for hospitalized patients in New York City. Clinical Infectious Diseases (2020). 
41. Shalev, N., Scherer, M., LaSota, E. D., Antoniou, P., Yin, M. T., Zucker, J. \& Sobieszczyk, M. E. Clinical Characteristics and Outcomes in People Living With Human Immunodeficiency Virus Hospitalized for Coronavirus Disease 2019. Clinical Infectious Diseases (2020).

42. Vizcarra, P., Pérez-Elıas, M. J., Quereda, C., Moreno, A., Vivancos, M. J., Dronda, F., Casado, J. L., Moreno, S., Pérez-Elıas, M. J., Fortún, J., et al. Description of COVID-19 in HIV-infected individuals: a single-centre, prospective cohort. The Lancet HIV (2020).

43. Stoeckle, K., Johnston, C. D., Jannat-Khah, D. P., Williams, S. C., Ellman, T. M., Vogler, M. A., Gulick, R. M., Glesby, M. J. \& Choi, J. J. COVID-19 in Hospitalized Adults With HIV in Open Forum Infectious Diseases 7 (2020), ofaa327.

44. Dandachi, D., Geiger, G., Montgomery, M. W., Karmen-Tuohy, S., Golzy, M., Antar, A. A. R., Llibre, J. M., Camazine, M., Díaz-De Santiago, A., Carlucci, P. M., Zacharioudakis, I. M., Rahimian, J., Wanjalla, C. N., Slim, J., Arinze, F., Kratz, A. M. P., Jones, J. L., Patel, S. M., Kitchell, E., Francis, A., Ray, M., Koren, D. E., Baddley, J. W., Hill, B., Sax, P. E. \& Chow Jeremy, H. I. V.-C. D. 2. (.-C.-1. C. Characteristics, Comorbidities, and Outcomes in a Multicenter Registry of Patients with HIV and Coronavirus Disease-19. Clinical Infectious Diseases (2020).

45. Haerter, G., Spinner, C. D., Roider, J., Bickel, M., Krznaric, I., Grunwald, S., Schabaz, F., Gillor, D., Postel, N., Mueller, M. C., et al. COVID-19 in people living with human immunodeficiency virus: a case series of 33 patients. Infection, 1 (2020).

46. Karmen-Tuohy, S., Carlucci, P. M., Zervou, F. N., Zacharioudakis, I. M., Rebick, G., Klein, E., Reich, J., Jones, S. \& Rahimian, J. Outcomes among HIV-positive patients hospitalized with COVID-19. Journal of acquired immune deficiency syndromes (1999) (2020).

47. Richardson, S., Hirsch, J. S., Narasimhan, M., Crawford, J. M., McGinn, T., Davidson, K. W., Barnaby, D. P., Becker, L. B., Chelico, J. D., Cohen, S. L., et al. Presenting characteristics, comorbidities, and outcomes among 5700 patients hospitalized with COVID-19 in the New York City area. Jama (2020).

48. Inciarte, A., Gonzalez-Cordon, A., Rojas, J., Torres, B., de Lazzari, E., de la Mora, L., MartinezRebollar, M., Laguno, M., Callau, P., Gonzalez-Navarro, A., Leal, L., Garcia, F., Mallolas, J., Mosquera, M., Marcos, M. A., Ambrosioni, J., Miro, J. M., Martinez, E. \& Blanco, J. L. Clinical characteristics, risk factors, and incidence of symptomatic coronavirus disease 2019 in a large cohort of adults living with HIV: a single-center, prospective observational study. AIDS 34, 1775-1780. ISSN: 1473-5571 (Electronic) 0269-9370 (Linking). https://www.ncbi.nlm.nih.gov/pubmed/32773471 (2020).

49. Hadi, Y. B., Naqvi, S. F. Z., Kupec, J. T. \& Sarwari, A. R. Characteristics and outcomes of COVID-19 in patients with HIV: a multicentre research network study. AIDS 34, F3-F8. ISSN: 1473-5571 (Electronic) 0269-9370 (Linking). https://www.ncbi.nlm.nih.gov/pubmed/32796217 (2020).

50. Hoffmann, C., Casado, J. L., Härter, G., Vizcarra, P., Moreno, A., Cattaneo, D., Meraviglia, P., Spinner, C. D., Schabaz, F., Grunwald, S., et al. Immune deficiency is a risk factor for severe COVID-19 in people living with HIV. HIV medicine (2020).

51. Avelino-Silva, V. I., Miyaji, K. T., Mathias, A., Costa, D. A., de Carvalho Dias, J. Z., Lima, S. B., Simoes, M., Freire, M. S., Caiaffa-Filho, H. H., Hong, M. A., et al. CD4/CD8 ratio predicts yellow fever vaccine-induced antibody titers in virologically suppressed HIV-infected patients. JAIDS Journal of Acquired Immune Deficiency Syndromes 71, 189-195 (2016).

52. Carson, P. J., Schut, R. L., Simpson, M. L., O'Brien, J. \& Janoff, E. N. Antibody class and subclass responses to pneumococcal polysaccharides following immunization of human immunodeficiency virus-infected patients. Journal of infectious diseases 172, 340-345. ISSN: 1537-6613 (1995).

53. Cooper, C., Thorne, A., Klein, M., Conway, B., Boivin, G., Haase, D., Shafran, S., Zubyk, W., Singer, J., Halperin, S., et al. Immunogenicity is not improved by increased antigen dose or booster dosing of seasonal influenza vaccine in a randomized trial of HIV infected adults. PloS one $\mathbf{6}$, e17758 (2011). 
54. Fuster, F., Vargas, J. I., Jensen, D., Sarmiento, V., Acuña, P., Peirano, F., Fuster, F., Arab, J. P., Martınez, F., Soto, S., et al. CD4/CD8 ratio as a predictor of the response to HBV vaccination in HIV-positive patients: A prospective cohort study. Vaccine 34, 1889-1895 (2016).

55. Shinde, V., Bhikha, S., Hoosain, Z., Archary, M., Bhorat, Q., Fairlie, L., Lalloo, U., Masilela, M. S., Moodley, D., Hanley, S., et al. Efficacy of NVX-CoV2373 Covid-19 Vaccine against the B. 1.351 Variant. New England Journal of Medicine 384, 1899-1909 (2021).

56. Cele, S., Gazy, I., Jackson, L., Hwa, S. H., Tegally, H., Lustig, G., Giandhari, J., Pillay, S., Wilkinson, E., Naidoo, Y., Karim, F., Ganga, Y., Khan, K., Bernstein, M., Balazs, A. B., Gosnell, B. I., Hanekom, W., Moosa, M. S., Network for Genomic Surveillance in South, A., Team, C.-K., Lessells, R. J., de Oliveira, T. \& Sigal, A. Escape of SARS-CoV-2 501Y.V2 from neutralization by convalescent plasma. Nature 593, 142-146. ISSN: 1476-4687 (Electronic) 0028-0836 (Linking). https://www.ncbi.nlm.nih.gov/pubmed/33780970 (2021).

57. Wibmer, C. K., Ayres, F., Hermanus, T., Madzivhandila, M., Kgagudi, P., Oosthuysen, B., Lambson, B. E., de Oliveira, T., Vermeulen, M., van der Berg, K., Rossouw, T., Boswell, M., Ueckermann, V., Meiring, S., von Gottberg, A., Cohen, C., Morris, L., Bhiman, J. N. \& Moore, P. L. SARS-CoV-2 501Y.V2 escapes neutralization by South African COVID-19 donor plasma. Nat Med 27, 622-625. ISSN: 1546-170X (Electronic) 1078-8956 (Linking). https ://www.ncbi.nlm.nih.gov/pubmed/ 33654292 (2021).

58. Garcia-Beltran, W. F., Lam, E. C., St Denis, K., Nitido, A. D., Garcia, Z. H., Hauser, B. M., Feldman, J., Pavlovic, M. N., Gregory, D. J., Poznansky, M. C., Sigal, A., Schmidt, A. G., Iafrate, A. J., Naranbhai, V. \& Balazs, A. B. Multiple SARS-CoV-2 variants escape neutralization by vaccineinduced humoral immunity. Cell 184, 2523. ISSN: 1097-4172 (Electronic) 0092-8674 (Linking). https://www.ncbi.nlm.nih.gov/pubmed/33930298 (2021).

59. Hoffmann, M., Arora, P., Groß, R., Seidel, A., Hörnich, B., Hahn, A., Krüger, N., Graichen, L., Hofmann-Winkler, H., Kempf, A., Winkler, M. S., Schulz, S., Jäck, H., Jahrsdörfer, B., Schrezenmeier, H., Müller, M., Kleger, A., Münch, J. \& Pöhlmann, S. SARS-CoV-2 variants B.1.351 and B.1.1.248: Escape from therapeutic antibodies and antibodies induced by infection and vaccination. bioRxiv. eprint: https://www. biorxiv. org/content/early/2021/02/11/2021.02.11.430787.full.pdf. https://www.biorxiv.org/content/early/2021/02/11/2021.02.11.430787 (2021).

60. Madhi, S. A., Baillie, V., Cutland, C. L., Voysey, M., Koen, A. L., Fairlie, L., Padayachee, S. D., Dheda, K., Barnabas, S. L., Bhorat, Q. E., Briner, C., Kwatra, G., Ahmed, K., Aley, P., Bhikha, S., Bhiman, J. N., Bhorat, A. E., du Plessis, J., Esmail, A., Groenewald, M., Horne, E., Hwa, S. H., Jose, A., Lambe, T., Laubscher, M., Malahleha, M., Masenya, M., Masilela, M., McKenzie, S., Molapo, K., Moultrie, A., Oelofse, S., Patel, F., Pillay, S., Rhead, S., Rodel, H., Rossouw, L., Taoushanis, C., Tegally, H., Thombrayil, A., van Eck, S., Wibmer, C. K., Durham, N. M., Kelly, E. J., Villafana, T. L., Gilbert, S., Pollard, A. J., de Oliveira, T., Moore, P. L., Sigal, A., Izu, A. \& Group, N.-S. G. W.-V. C. Efficacy of the ChAdOx1 nCoV-19 Covid-19 Vaccine against the B.1.351 Variant. $N$ Engl J Med. ISSN: 1533-4406 (Electronic) 0028-4793 (Linking). https://www.ncbi.nlm.nih.gov/pubmed/33725432 (2021).

61. Jassat, W., Mudara, C., Ozougwu, L., Tempia, S., Blumberg, L., Davies, M.-A., Pillay, Y., Carter, T., Morewane, R., Wolmarans, M., et al. Difference in mortality among individuals admitted to hospital with COVID-19 during the first and second waves in South Africa: a cohort study. The Lancet Global Health (2021).

62. Karim, F., Moosa, M., Gosnell, B., Cele, S., Giandhari, J., Pillay, S., Tegally, H., Wilkinson, E., San, J., Msomi, N., Mlisana, K., Khan, K., Bernstein, M., Manickchund, N., Singh, L., Ramphal, U., Hanekom, W., Lessells, R., Sigal, A. \& de Oliveira, T. Persistent SARS-CoV-2 infection and intra-host evolution in association with advanced HIV infection. medRxiv. eprint: https : //www. medrxiv .org/content/early/2021/06/04/2021.06.03.21258228.full.pdf. https: //www.medrxiv.org/content/early/2021/06/04/2021.06.03.21258228 (2021). 
63. Guo, K., Barrett, B. S., Mickens, K. L., Hasenkrug, K. J. \& Santiago, M. L. Interferon Resistance of Emerging SARS-CoV-2 Variants. bioRxiv. eprint: https://www.biorxiv.org/content/early/ 2021/03/21/2021.03.20.436257.full.pdf. https://www.biorxiv.org/content/early/2021/ 03/21/2021.03.20.436257 (2021).

64. Thorne, L. G., Bouhaddou, M., Reuschl, A.-K., Zuliani-Alvarez, L., Polacco, B., Pelin, A., Batra, J., Whelan, M. V., Ummadi, M., Rojc, A., et al. Evolution of enhanced innate immune evasion by the SARS-CoV-2 B. 1.1. 7 UK variant. bioRxiv (2021).

65. Rajah, M. M., Hubert, M., Bishop, E., Saunders, N., Robinot, R., Grzelak, L., Planas, D., Zivaljic, M., Planchais, C., Guivel-Benhassine, F., Porrot, F., Mouquet, H., Chakrabarti, L., Buchrieser, J. \& Schwartz, O. B.1.1.7 and B.1.351 SARS-CoV-2 variants display enhanced Spike-mediated fusion. bioRxiv. eprint: https://www. biorxiv.org/content/early/2021/06/11/2021.06.11.448011. full.pdf. https://www.biorxiv.org/content/early/2021/06/11/2021.06.11.448011 (2021).

66. Zhou, F., Yu, T., Du, R., Fan, G., Liu, Y., Liu, Z., Xiang, J., Wang, Y., Song, B. \& Gu, X. Clinical course and risk factors for mortality of adult inpatients with COVID-19 in Wuhan, China: a retrospective cohort study. The lancet. ISSN: 0140-6736 (2020).

67. Van Heerden, A., Barnabas, R. V., Norris, S. A., Micklesfield, L. K., van Rooyen, H. \& Celum, C. High prevalence of HIV and non-communicable disease (NCD) risk factors in rural KwaZulu-Natal, South Africa. Journal of the international AIDS society 20, e25012 (2017).

68. Malaza, A., Mossong, J., Bärnighausen, T. \& Newell, M.-L. Hypertension and obesity in adults living in a high HIV prevalence rural area in South Africa. PloS one 7, e47761 (2012).

69. Federation, I. D. IDF diabetes atlas ninth edition 2019 (2019).

70. Ryscavage, P., Kelly, S., Li, J. Z., Harrigan, P. R. \& Taiwo, B. Significance and clinical management of persistent low-level viremia and very-low-level viremia in HIV-1-infected patients. Antimicrobial agents and chemotherapy 58, 3585-3598 (2014).

71. Sanz, I., Wei, C., Jenks, S. A., Cashman, K. S., Tipton, C., Woodruff, M. C., Hom, J. \& Lee, F. Challenges and opportunities for consistent classification of human B cell and plasma cell populations. Frontiers in immunology 10, 2458 (2019).

72. Khodadadi, L., Cheng, Q., Radbruch, A. \& Hiepe, F. The maintenance of memory plasma cells. Frontiers in immunology 10, 721 (2019).

73. Sauce, D., Almeida, J. R., Larsen, M., Haro, L., Autran, B., Freeman, G. J. \& Appay, V. PD-1 expression on human CD8 T cells depends on both state of differentiation and activation status. Aids 21, 2005-2013 (2007).

74. Vollbrecht, T., Brackmann, H., Henrich, N., Roeling, J., Seybold, U., Bogner, J. R., Goebel, F. D. \& Draenert, R. Impact of changes in antigen level on CD38/PD-1 co-expression on HIV-specific CD8 T cells in chronic, untreated HIV-1 infection. Journal of medical virology 82, 358-370 (2010).

75. Groom, J. R. \& Luster, A. D. CXCR3 in T cell function. Experimental cell research 317, 620-631 (2011).

76. Yang, X., Yu, Y., Xu, J., Shu, H., Liu, H., Wu, Y., Zhang, L., Yu, Z., Fang, M., Yu, T., et al. Clinical course and outcomes of critically ill patients with SARS-CoV-2 pneumonia in Wuhan, China: a single-centered, retrospective, observational study. The Lancet Respiratory Medicine $\mathbf{8}$, 475-481 (2020).

77. Guan, W.-j., Ni, Z.-y., Hu, Y., Liang, W.-h., Ou, C.-q., He, J.-x., Liu, L., Shan, H., Lei, C.-l., Hui, D. S., et al. Clinical characteristics of coronavirus disease 2019 in China. New England journal of medicine 382, 1708-1720 (2020).

78. Ambrosioni, J., Blanco, J. L., Reyes-Uruena, J. M., Davies, M. A., Sued, O., Marcos, M. A., Martinez, E., Bertagnolio, S., Alcami, J., Miro, J. M. \& Investigators, C. i. H. Overview of SARSCoV-2 infection in adults living with HIV. Lancet HIV 8, e294-e305. ISSN: 2352-3018 (Electronic) 2352-3018 (Linking). https://www.ncbi.nlm.nih.gov/pubmed/33915101 (2021). 
medRxiv preprint doi: https://doi.org/10.1101/2020.11.23.20236828; this version posted September 5, 2021. The copyright holder for this preprint

(which was not certified by peer review) is the author/funder, who has granted medRxiv a license to display the preprint in perpetuity.

\begin{abstract}
It is made available under a CC-BY-ND 4.0 International license .
\end{abstract}
79. Chen, Z. \& Wherry, E. J. T cell responses in patients with COVID-19. Nature Reviews Immunology 20, 529-536 (2020).

80. Rodda, L. B., Netland, J., Shehata, L., Pruner, K. B., Morawski, P. A., Thouvenel, C. D., Takehara, K. K., Eggenberger, J., Hemann, E. A., Waterman, H. R., et al. Functional SARS-CoV-2-specific immune memory persists after mild COVID-19. Cell 184, 169-183 (2021). 
medRxiv preprint doi: https://doi.org/10.1101/2020.11.23.20236828; this version posted September 5, 2021. The copyright holder for this preprint (which was not certified by peer review) is the author/funder, who has granted medRxiv a license to display the preprint in perpetuity.

It is made available under a CC-BY-ND 4.0 International license .

${ }_{676}$ Supplementary Data

Supplementary File 1: Summary of case visits

\begin{tabular}{ccc}
\hline Timepoint & Visit & Participants \\
\hline 1 & Enrollment & $236(100.0)$ \\
2 & DAY 7 & $157(66.5)$ \\
3 & DAY 14 & $139(58.9)$ \\
4 & DAY 21 & $125(53.0)$ \\
5 & DAY 28 & $142(60.2)$ \\
6 & MONTH 3 & $87(36.9)$ \\
7 & MONTH 6 & $72(30.5)$ \\
8 & MONTH 9 & $24(10.2)$ \\
Unscheduled visits & - & $4(1.7)$ \\
Total case visits & - & 986 \\
\hline
\end{tabular}


Supplementary File 2: Timing of enrollment in PLWH and HIV negative participants

\begin{tabular}{lccc}
\hline & All Participants & HIV- & HIV+ \\
\hline $\begin{array}{l}\text { Median (IQR) days symptom onset to } \\
\text { enrollment }\end{array}$ & $11(8-18)$ & $11(8-18)$ & $11(8-18)$ \\
$\begin{array}{l}\text { Median (IQR) days diagnostic swab to } \\
\text { enrollment }\end{array}$ & $8(5-14)$ & $8.5(5-17.5)$ & $7.5(5-10)$ \\
$\begin{array}{l}\text { Median (IQR) days symptom onset to } \\
\text { diagnostic swab }\end{array}$ & $3(1-6)$ & $3(2-6)$ & $3(1-7)$ \\
\hline
\end{tabular}


Supplementary File 3: ART regimen in PLWH as determined by LC-MS/MS

LC-MS/MS DETERMINED REGIMEN

EFV based regimen

EFV regimen transitioning to DTG regimen

NVP/AZT based regimen

DTG based regimen

$\mathrm{LPV} / \mathrm{r}$ based regimen

ATV based regimen

Combination of TFV, FTC, or 3TC only

No detectible ART yet record of ART regimen

ART naïve

Information not available
NUMBER OF PARTICIPANTS (\%)

41 (44.1)

15 (16.1)

3 (3.2)

4 (4.3)

6 (6.5)

3 (3.2)

5 (5.4)

5 (5.4)

6 (6.5)

$5(5.4)$ 
Supplementary File 4: Infection wave 1 COVID-19 disease severity by HIV status

\begin{tabular}{lccccc}
\hline & $\begin{array}{c}\text { All } \\
(\mathbf{n = 1 5 3 )}\end{array}$ & $\begin{array}{c}\text { HIV- } \\
(\mathbf{n = 9 0 , 5 8 . 8 \% )}\end{array}$ & $\begin{array}{c}\text { HIV+ } \\
(\mathbf{n}=\mathbf{6 3}, \mathbf{4 1 . 2 \% )}\end{array}$ & $\begin{array}{c}\text { Odds Ratio } \\
(\mathbf{9 5 \%} \mathbf{C l})\end{array}$ & p-value $^{\#}$ \\
\hline Asymptomatic & $25(16.3)$ & $18(20.0)$ & $7(11.1)$ & $0.5(0.2-1.3)$ & 0.18 \\
Ambulatory with symptoms & $89(58.2)$ & $51(56.7)$ & $38(60.3)$ & $1.2(0.6-2.2)$ & 0.74 \\
Supplemental oxygen & $32(20.9)$ & $17(18.9)$ & $15(23.8)$ & $1.3(0.6-2.9)$ & 0.54 \\
Death & $7(4.6)$ & $4(4.4)$ & $3(4.8)$ & $1.1(0.3-4.5)$ & $>0.99$ \\
\hline
\end{tabular}

\#p-value calculated via 2-sided Fisher's Exact test. 
Supplementary File 5: Infection wave 2 COVID-19 disease severity by HIV status

\begin{tabular}{lccccc}
\hline & $\begin{array}{c}\text { All } \\
(\mathbf{n = 8 3})\end{array}$ & $\begin{array}{c}\text { HIV- } \\
(\mathbf{n}=\mathbf{5 3 , 6 3 . 9 \% )}\end{array}$ & $\begin{array}{c}\text { HIV+ } \\
(\mathbf{n}=\mathbf{3 0 , 3 6 . 1 \% )}\end{array}$ & $\begin{array}{c}\text { Odds Ratio } \\
(\mathbf{9 5 \%} \mathbf{C l})\end{array}$ & p-value $^{\#}$ \\
\hline Asymptomatic & $8(9.6)$ & $7(13.2)$ & $1(3.3)$ & $0.2(<0.1-1.5)$ & 0.25 \\
Ambulatory with symptoms & $39(47.0)$ & $29(54.7)$ & $10(33.3)$ & $0.4(0.2-1.0)$ & 0.071 \\
Supplemental oxygen & $30(36.1)$ & $13(24.5)$ & $17(56.7)$ & $\mathbf{4 . 0 ( 1 . 6 - 1 0 . 4 )}$ & $\mathbf{0 . 0 0 5}$ \\
Death & $6(7.2)$ & $4(7.5)$ & $2(6.7)$ & $0.9(<0.1-4.4)$ & $>0.99$ \\
\hline
\end{tabular}

\#p-value calculated via 2-sided Fisher's Exact test. 
Supplementary File 6: Comparison between HIV negative participants requiring and not requiring supplemental oxygen

\begin{tabular}{|c|c|c|c|c|c|}
\hline & $\begin{array}{c}\text { All } \\
(n=143)\end{array}$ & $\begin{array}{c}\text { No Supp. } O_{2} \\
(n=108,75.5 \%)\end{array}$ & $\begin{array}{c}\text { Supp. } O_{2} \\
(n=35,24.5 \%)\end{array}$ & $\begin{array}{c}\text { Odds Ratio } \\
(95 \% \mathrm{Cl})\end{array}$ & p-value \\
\hline \multicolumn{6}{|l|}{ Demographics } \\
\hline Age years, median (IQR) & $49(35-62)$ & $46.5(34-57)$ & $62(47-66)$ & - & $0.002 *$ \\
\hline \multicolumn{6}{|l|}{ Comorbidity, n (\%) } \\
\hline Hypertension $\$, n=142$ & $42(29.4)$ & $24(22.2)$ & $18(51.4)$ & $3.7(1.7-8.1)$ & 0.002 \\
\hline Diabetes & $32(22.4)$ & $19(17.6)$ & $13(37.1)$ & $2.8(1.2-6.4)$ & 0.021 \\
\hline Obesity $\$$ n= 136 & $64(47.1)$ & $53(40.1)$ & $11(31.4)$ & $0.5(0.2-1.1)$ & 0.11 \\
\hline Active TB & $1(0.7)$ & $0(0.0)$ & $1(2.9)$ & $<0.1(0->10)$ & 0.25 \\
\hline History TB & $3(2.1)$ & $1(0.9)$ & $2(5.7)$ & $6.5(0.8->10)$ & 0.15 \\
\hline \multicolumn{6}{|l|}{ COVID-19 treatment, $n$ (\%) } \\
\hline Corticosteroids & 47 (32.9) & $22(20.4)$ & $25(71.4)$ & $9.8(4.1->10)$ & $<0.0001$ \\
\hline Anticoagulants & $35(24.5)$ & $17(15.7)$ & $18(51.4)$ & $5.7(2.5->10)$ & 0.0001 \\
\hline
\end{tabular}

\#p-value calculated via 2-sided Fisher's Exact test, except for * which was calculated via Mann-Whitney U test. ${ }^{\$}$ Not including pregnancy or unable to be measured. 
Supplementary File 7: Comparison between PLWH requiring and not requiring supplemental oxygen

\begin{tabular}{|c|c|c|c|c|c|}
\hline & $\begin{array}{c}\text { All } \\
(n=93)\end{array}$ & $\begin{array}{c}\text { No Supp. } O_{2} \\
(n=60,64.5 \%)\end{array}$ & $\begin{array}{c}\text { Supp. } \mathrm{O}_{2} \\
(\mathrm{n}=33,35.5 \%)\end{array}$ & $\begin{array}{c}\text { Odds Ratio } \\
(95 \% \mathrm{Cl})\end{array}$ & p-value \\
\hline \multicolumn{6}{|l|}{ Demographic characteristic } \\
\hline Age years, median (IQR) & $41(35-50)$ & 40.5 (34-49) & $41(36-56)$ & - & $0.295^{*}$ \\
\hline \multicolumn{6}{|l|}{ Comorbidity, n (\%) } \\
\hline Hypertension & $15(16.1)$ & $7(11.7)$ & $8(24.2)$ & $2.4(0.8-7.2)$ & 0.144 \\
\hline Diabetes & $10(10.8)$ & $6(10.0)$ & $4(12.1)$ & $1.2(0.3-4.5)$ & 0.739 \\
\hline Obesity $\$$, n= 79 & $27(34.2)$ & $15(25.0)$ & $12(36.4)$ & $2.4(0.9-6.4)$ & 0.125 \\
\hline Active TB & $9(9.7)$ & $4(6.7)$ & $5(15.2)$ & $2.5(0.7-9.3)$ & 0.272 \\
\hline History TB & $29(31.2)$ & $15(25.0)$ & $14(42.4)$ & $2.2(0.9-5.4)$ & 0.103 \\
\hline \multicolumn{6}{|l|}{ COVID-19 treatment, n (\%) } \\
\hline Corticosteroids & $27(29.0)$ & $9(15.0)$ & $18(54.5)$ & $6.8(2.6->10)$ & 0.0001 \\
\hline Anticoagulants & $18(19.4)$ & $5(8.3)$ & $13(39.4)$ & $7.2(2.3->10)$ & 0.001 \\
\hline
\end{tabular}




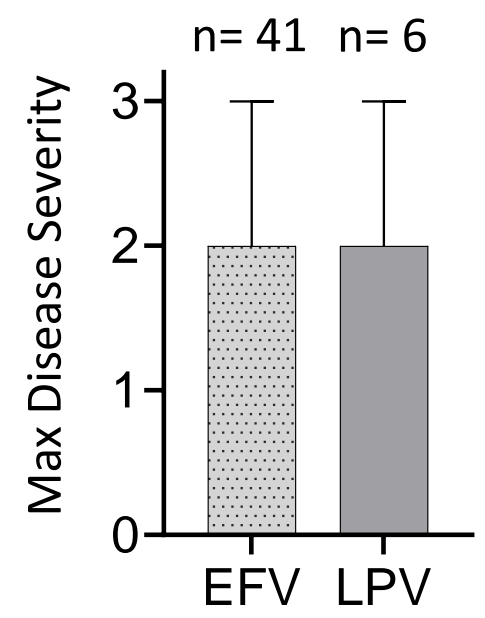

Figure 1-figure supplement 1: Effect of ART regimen on disease severity. Disease severity scored on a 3 point scale, where 1: asymptomatic, 2: mild, and 3: supplemental oxygen or death. 
HIV negative

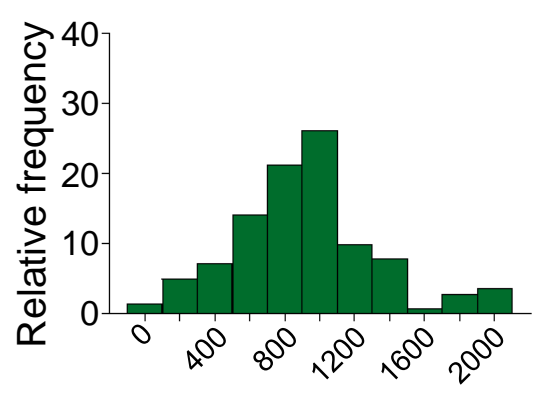

HIV ART suppressed

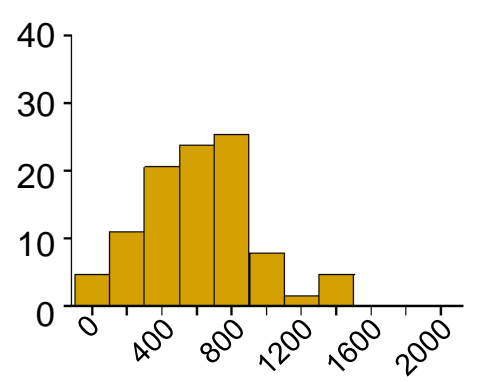

Median CD4 Count (cells/ $\mu \mathrm{L}$ )
HIV viremic

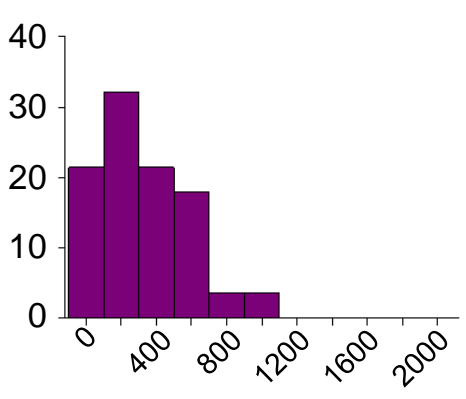

Figure 1-figure supplement 2: Distribution of CD4 counts by HIV status. Plotted are the CD4 T cell count distributions for HIV negative, HIV ART suppressed, and HIV viremic participants. X-axis is the median CD4 count over all study visits, and y-axis is relative frequency of participants as percentage. 
A

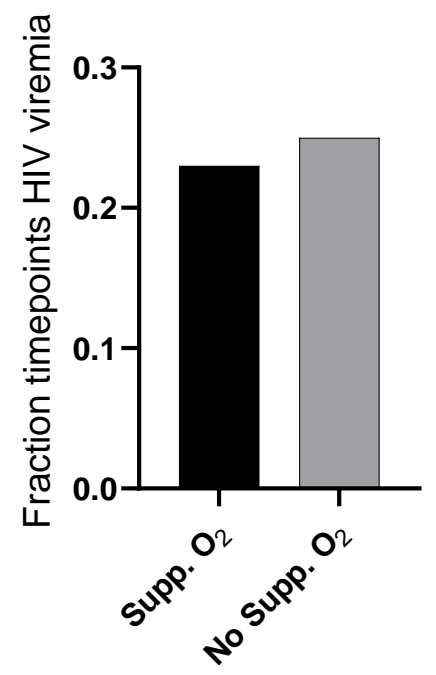

B

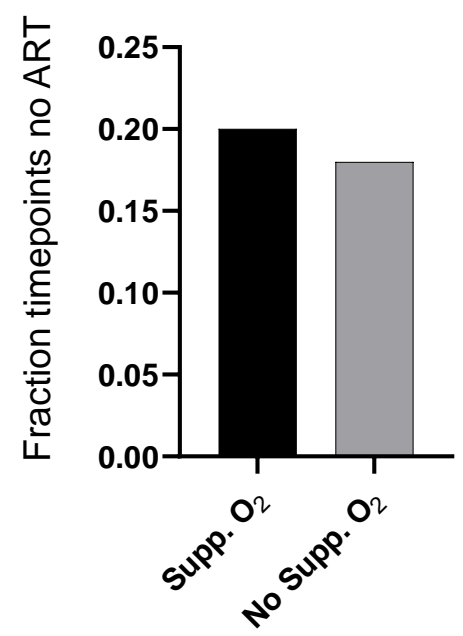

Figure 1-figure supplement 3: Viremia and ART in PLWH requiring versus not requiring supplemental oxygen. (A) HIV viremia was calculated as the number of study timepoints with HIV RNA > 200 copies/ml divided by all measured timepoints for PLWH. (B) The fraction of timepoints with no detectable ART was calculated as the number of study timepoints where the concentration of none of the ART components was above level of quantification divided by all measured PLWH timepoints. No significance for comparison in (A) or (B) as determined by Fisher's Exact test. 
A

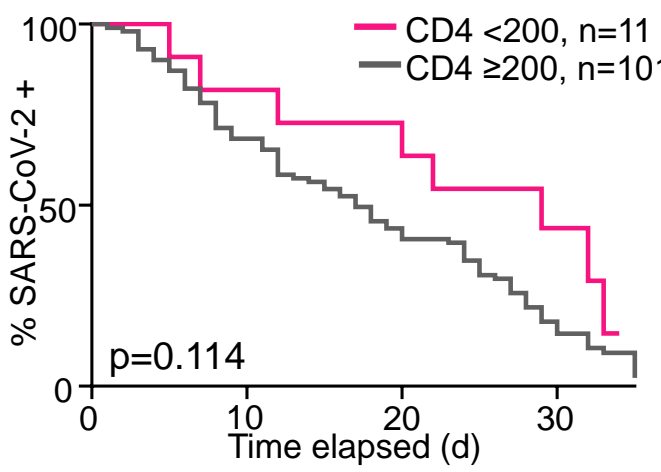

B

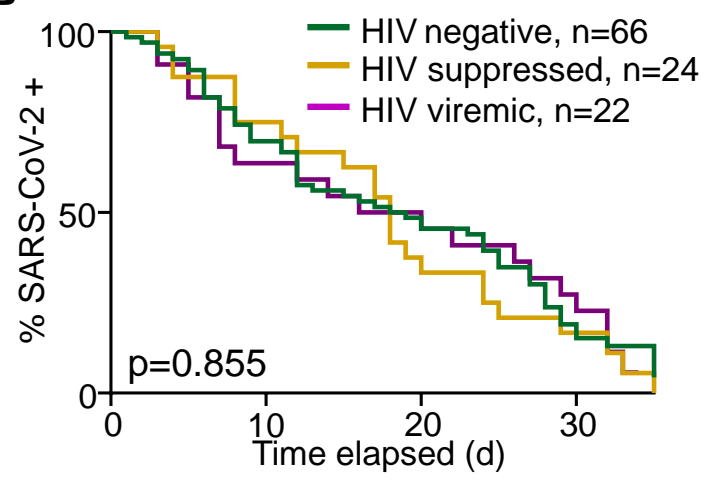

Figure 1-figure supplement 4: Dependence of time to SARS-CoV-2 clearance on CD4 count and HIV status. (A) Number of participants remaining SARS-CoV-2 positive by qPCR with time as a function of CD4 count. (B) Number of participants remaining SARS-CoV-2 positive by qPCR with time as a function of HIV status. Time is days post-diagnostic swab. Only participants who were tested with two conclusive tests result (either SARS-CoV-2 positive or negative) during the time-period were included. 
A

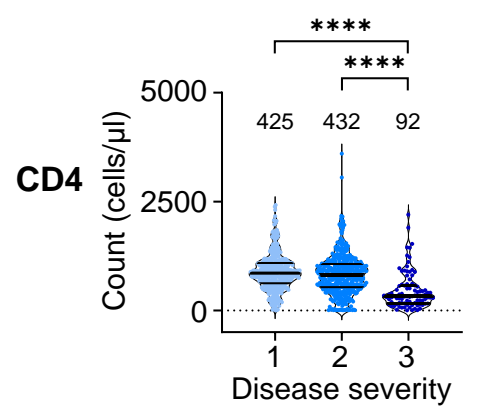

D

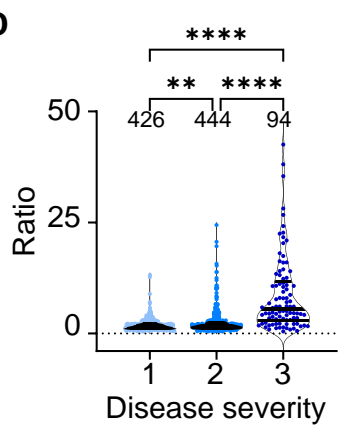

B

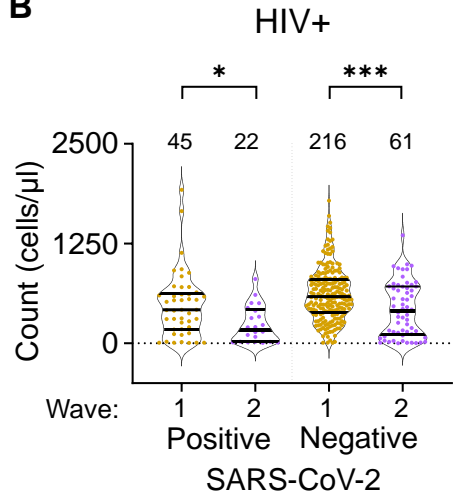

$\mathbf{E}$

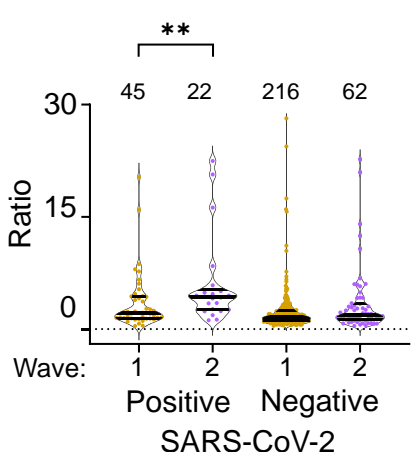

C

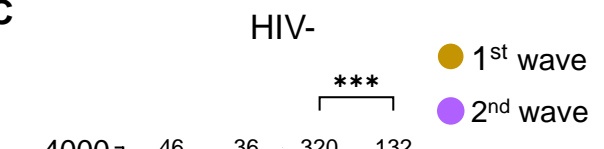

Figure 2-figure supplement 1: The differential effect of HIV on the CD4 count and neutrophil to lymphocyte ratio between waves - full dataset and number of data points per plot. (A) The concentration of CD4 $\mathrm{T}$ cells in the blood in all participants in all infection waves and at all time-points as a function of disease severity. Disease severity was scored as 1: asymptomatic, 2: mild, and 3: requiring supplemental oxygen and/or death. CD4 counts in PLWH (B) and HIV negative (C) participants in waves 1 versus waves 2 during active SARS-CoV-2 in during active SARS-CoV-2 infection and after SARS-CoV-2 clearance. (D) Neutrophil to lymphocyte ratio (NLR) in the blood in all participants in all infection waves and at all time-points as a function of disease severity. NLR in PLWH (E) and HIV negative (F) participants in waves 1 versus waves 2 during active SARS-CoV-2 in during active SARS-CoV-2 infection and after SARS-CoV-2 clearance. SARS-CoV-2 positive indicates a timepoint where SARS-CoV-2 RNA was detected in the upper respiratory tract. Data shown as violin plots with median and IQR, with the median also denoted below each plot. Fold-change in the second wave versus first wave is indicated by the number above the second wave data, with arrow denoting direction of change. p-values are ${ }^{*}<0.05 ;{ }^{* *}<0.01 ; * * *<0.001,{ }^{* * * *}<0.0001$ as determined by Kruskal-Wallis test with Dunn's multiple comparison correction for the left plots or by Mann-Whitney U test for the other data. 
A

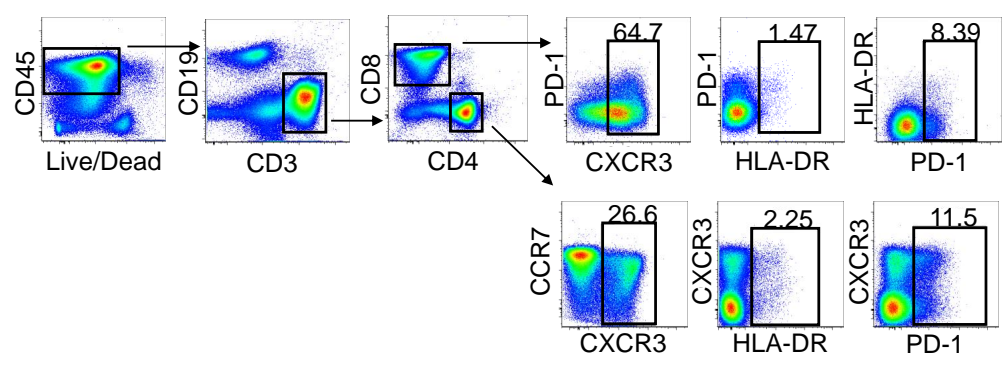

B

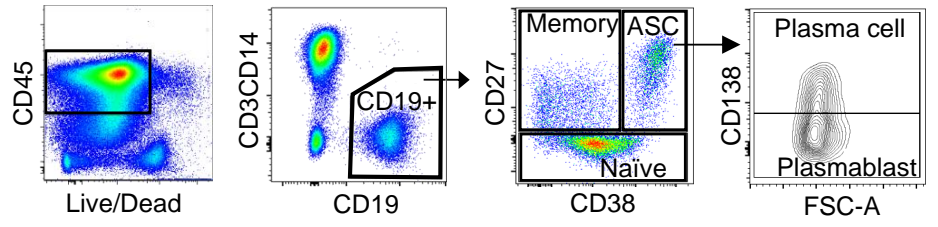

C

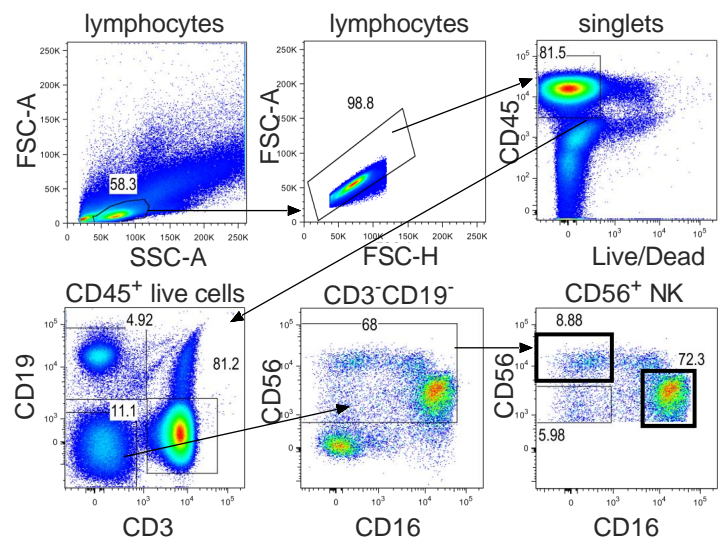

Figure 3-figure supplement 1: Gating strategy. (A) Gating of T cell subsets. Live CD3+ cells were gated into CD4+ and CD8+ subsets, which were further divided based on CXCR3, HLA-DR, and PD-1 for CD8 T cells and CXCR3, CCR7, HLA-DR, and PD-1 for CD4 T cells. (B) Gating of B cell subsets. Live CD19+ cells were subdivided into memory, naive, and antibody secreting cells (ASC) based on CD27 and CD38. ASC were further subdivided into plasma cells and plasmablasts based on CD138. 